\title{
Dynamic liquefaction of shear zones in intact loess during simulated earthquake loading
}

\section{J. M. Carey ${ }^{1}$, M. J. McSaveney ${ }^{1}$ \& D.N.Petley ${ }^{2}$}

${ }^{1}$ GNS Science, 1 Fairway Drive Avalon, PO Box 30368 Lower Hutt, New Zealand

${ }^{2}$ School of Environmental Sciences, University of East Anglia, Norwich, NR4 7TJ, $U K$

\section{ABSTRACT}

The 2010-2011 Canterbury earthquake sequence in New Zealand exposed loessmantled slopes in the area to very high levels of seismic excitation (locally measured as $>2 \mathrm{~g}$ ). Few loess slopes showed permanent local downslope deformation, and most of these showed only limited accumulated displacement. A series of innovative dynamic back pressured shear-box tests were undertaken on intact and remoulded loess samples collected from one of the recently active slopes replicating field conditions under different simplified horizontal seismic excitations. During each test, the strength reduction and excess pore water pressures generated were measured as the sample failed. Test results suggest that although dynamic liquefaction could have occurred, a key factor was likely to have been that the loess was largely unsaturated at the times of the large earthquake events.

The failure of intact loess samples in the tests was complex and variable due to the highly variable geotechnical characteristics of the material. Some loess samples failed rapidly as a result of dynamic liquefaction as seismic excitation generated an increase in pore-water pressure, triggering rapid loss of strength and thus of shear resistance. Following initial failure, pore pressure dissipated with continued seismic excitation and the sample consolidated, resulting in partial shear-strength recovery. Once excess pore-water pressures had dissipated, deformation continued in a critical effective stress state with no further change in volume. Remoulded and weaker samples, however, did not liquefy, and instead immediately reduced in volume with an accompanying slower and more sustained increase in pore pressure as the sample consolidated. Thereafter excess pressures dissipated and deformation continued at a critical state. 
35 The complex behaviour explained why, despite exceptionally strong ground shaking,

36 there was only limited displacement and lack of run-out: dynamic liquefaction was

37 unlikely to occur in the freely draining slopes. Dynamic liquefaction however 38 remained a plausible mechanism to explain loess failure in some of the low-angle toe 39 slopes, where a permanent water table was present in the loess.

40 


\section{INTRODUCTION}

42 Catastrophic landslides, particularly during earthquakes, are a significant hazard due to their often rapid development, long run-out and subsequent disastrous consequences (Wang et al. 2014). Whilst the global extent of loess landslides is well known, (e.g. Zou and Shao 1996; Wen et al. 2004; Xu et al. 2007) the mechanism through which they develop during earthquakes remains to be fully understood. Although it is generally accepted that a majority of earthquake-induced landslides occur through liquefaction (Seed 1966), defined by Castro et al., (1982) as a condition where a soil mass loses a large percentage of its shear resistance, when subject to monotonic, cyclic or shock undrained loading and flows in a manner resembling a liquid until the shear stresses acting on the mass are as low as the reduced friction. Laboratory based testing of loose sands (e.g. McRoberts and Sladen 1992; Sasitharan et al. 1993) have demonstrated that liquefaction can occur in both undrained and drained conditions as a result of rapid excess pore water pressure development resulting in a sudden dramatic loss in shear resistance.

In the case of loess slopes, a number of potential mechanisms have been alluded to. Assessments of the 1920 Hiyuan earthquake by Varnes (1978) suggested failures occurred as dry loess flows as a result of high pore air pressures (Ter-Stepanian 1998). More recent studies however (Fletcher et al. 2002; Wang and Sassa 2002; Wang et al. 2007; Zhang et al. 2013) indicate that soils composed almost entirely of silts are liquefiable. In addition more detailed geomorphological studies of landslides (e.g. Zhang et al. 1995; Zhang and Sassa 1996; Zhang and Wang 2007) find that the slope failures occur from sloping source areas $\left(20^{\circ}\right)$ on concave slopes and conclude that the highly mobile loess landslides are activated through liquefaction.

Loess covers $10 \%$ of the land surface of the South Island of New Zealand, and is also present within the southern part of the North Island. Its wind-blown depositional characteristics result in sediments that can mantle steep rock slopes, and which can stand in vertical faces. In February 2011, a strong, shallow earthquake occurred directly beneath the loess-covered Port Hills of Christchurch, New Zealand (Fig. 1), generating unusually high ground accelerations (Kaiser et al. 2012). It was part of a series of earthquakes known as the 2010-11 Canterbury Earthquake sequence. Following the February 2011 earthquake, 36 large landslides were mapped, of which 
75 the majority were in fine-grained loess on the Canterbury Port Hills. A key issue that arose early in the ensuing aftershock sequence was whether further aftershocks could trigger more loess landslides and if so, under what circumstances might they cause fatalities? Historical data for New Zealand indicated loess landslide fatalities during heavy rain, but not during strong earthquakes. International precedent is different: about 4000 people were killed in July 1949 in the earthquake-triggered Yasman valley loess flow in the vicinity of Khait, Tajikistan (Evans et al. 2009). The earthquake triggered numerous loess landslides and killed about 7200 people in total. A key factor there appears to have been that the loess was wet at the time of the earthquake, and landslide run-out was across saturated ground (Evans et al. 2009).

Despite advances in understanding the mechanisms of loess landslide development (e.g. Xu et al. 2007), further data are required on the performance of both intact and remoulded loess during seismic excitation. This study sought to explore this issue through an experimental investigation of loess behaviour during seismic excitation using samples from the Canterbury Port Hills. We took samples of intact primary airfall loess from near the Maffeys Road loess landslide (Massey et al. 2013), which moved about $0.7 \mathrm{~m}$ during the Canterbury Earthquake sequence without catastrophic failure leading to long run-out. The samples were tested in a Dynamic Back Pressured Shearbox (DBPSB, www.gdsinstruments.com, accessed 14 January 2015). The DBPSB is based on a standard direct-shear device, modified to allow the measurement and control of pore pressure and dynamic application of normal and shear stresses (Brain, et al. 2015). This device can be used for static and dynamic direct-shear testing of intact or remoulded soils with control of pore pressure to allow realistic landslide mechanisms to be simulated in the laboratory. Using this device we sought to explore whether earthquake shaking could induce loess slope failures by liquefaction as defined by Castro et al (1982), and why during the 2010-2011 earthquake sequence it did not.

\section{THE PORT HILLS AND THEIR LOESS CHARACTERISTICS}

The Christchurch Port Hills (hereafter referred to simply as the Port Hills) are located between the city of Christchurch and the port of Lyttelton on the South Island of New Zealand (Fig. 1). The Port Hills form the northern sector of the eroded extinct Lyttelton basalt volcano and the rocks belonging to the Miocene Lyttelton Volcanics 
109 Group. These rocks comprise layers of hard, jointed, basalt and trachy-basalt lava flows cut by dykes, and interbedded with breccia (scoria) and epiclastic deposits comprising agglomerate (coarse angular gravel), compact sandy tuff (ash and reworked ash), fluvial deposits (poorly sorted conglomerates and coarse sandstones), and ancient buried soils.

The eroded volcano is mantled by soils predominantly derived from wind-blown sand and silt (loess), of the Banks Peninsula Loess (Brown and Weeber, 1992). This loess forms a predominantly thick sheet $(>1 \mathrm{~m})$ over Banks Peninsular (Fig. 1). At least four periods of loess deposition, separated by periods of relative quiescence, and soil formation are recognised in the most complete sections of the Banks peninsula (Griffiths, 1973). It is a relatively cohesive, silt-dominated soil with only minor clay mineral content. Its mechanical properties when wet have been much studied (e.g. Bell et al. 1986; Bell and Trangmar 1987; McDowell 1989; Goldwater 1990; Yetton 1992; Carey et al. 2014). These studies indicate regional differences between loess from northern and southern Banks Peninsular, but little variation locally around the Port Hills.

The Canterbury Plains to the west of Banks Peninsula are extensive alluvial fans and the likely dominant source of the loess. The prevailing westerly winds access silt and fine sand from the braided channels of the rivers crossing the Canterbury Plains The river sediments are derived from mainly quartzofeldspathic greywacke sandstone and argillite of the Southern Alps. During sea level stands of up to $120 \mathrm{~m}$ below current level the fans extended east of Banks Peninsular and frequent easterly winds could also deposit loess in the Port Hills (Raeside 1964). Although there is much primary air-fall deposited loess, there is also much colluvially reworked loess (Griffiths, 1973), which is the expected outcome of air-fall deposition in a humid environment.

The surface morphology of Banks Peninsular is one of a deeply dissected volcano 'softened' by a mantle of loess that is thin and discontinuous at higher altitudes, but forming a thick layer (up to $20 \mathrm{~m}$ ) that almost totally blankets the lower slopes and spurs. Major historical colluvial activity has been episodic, limited to wet periods, with triggering of shallow slide/flows and extensive slope wash by high intensity rainstorms (Bell and Trangmar 1987). 
 \\ THE CANTERBURY EARTHQUAKE SEQUENCE}

The Canterbury earthquake sequence started on 4 September 2010 with an $M_{w} 7.1$ earthquake $40 \mathrm{~km}$ west of Christchurch at Darfield (Bannister and Glenhill 2012) (Fig. 1). The event was followed on 22 February 2011 by the $M_{w} 6.1$ Christchurch earthquake, which was centred $6 \mathrm{~km}$ southeast of the city centre beneath the northern edge of the Port Hills. This well recorded event had maximum vertical peak ground accelerations of $2.2 \mathrm{~g}$ (Kaiser et al. 2012). It triggered many landslides, mainly rockfalls and debris avalanches, over an area of $65 \mathrm{~km}^{2}$ of the Port Hills (Dellow et al. 2011). In the following 10 months there were over $85 \mathrm{M}_{\mathrm{w}} \geq 4.0$ aftershocks with epicentres close to or immediately below the Port Hills (Gledhill et al. 2011; Kaiser et al. 2012; Ristau et al. 2013), some of which triggered further landslides.

Each identified earthquake-induced mass movement was classified by failure type (Massey et al. 2014), primarily inferred from the materials and the movement style, based broadly on the landslide classification scheme of Cruden and Varnes (1996). Whilst many mass movement types were observed within the Port Hills, the majority of landslides within the loess were of two main types.

Failure type 1 comprised landslides from loess slopes overlying bedrock (Fig 2a). In some cases these failures were entirely within the loess and were not influenced by the underlying bedrock (Fig 2b). In other cases, failure occurred at the interface between the loess / loess colluvium and the rock beneath (Fig 2c). These failures typically occurred where thick $(>5 \mathrm{~m}$ ) loess mantled the tops of steep slopes (cliffs typically steeper than $60^{\circ}$ ) exposing volcanic rock. Despite significant deformation of these slopes, these failures did not develop into long run-out loess debris avalanches or flows as has been experienced in other earthquake events (Evans et al. 2009). Instead these failures typically generated a series of tension cracks with significant cumulative vertical (up to $1 \mathrm{~m}$ ) and horizontal displacement (up to $5 \mathrm{~m}$ ) in the loess mantled over the rock slope, causing local damage only.

Failure type 2 comprised large shallow slope slides or 'toe slumps' within the gentle valley-bottom loess slopes (Fig 2d). These failures mainly occurred in locations where 
176 low angle (typically less than $25^{\circ}$ ) slopes in the Port Hills graded into flatter areas of 177 the valley bottom, with permanent relatively high water tables (Fig 2e). 178 Displacements at these sites were generally less than $1.5 \mathrm{~m}$ and commonly resulted in 179 laterally extensive linear zones of property-damaging cracking and extension at the 180 crest of the failure. The main body of the landslide downslope was simply translated 181 with limited damage to property. At the toe was another zone of extensive property 182 damage, but from compression. The toe area also showed evidence of water saturation 183 (water springs, ponding and sand boils), which was not merely from broken service 184 pipes.

185

186 Both types caused much property damage, but neither was associated with fatalities. 187 This stood in marked contrast with the historical record, where there have been three 188 deaths from rainfall-induced loess-on-rock failures recorded on Banks Peninsula, 189 however, these did not occur in the Port Hills (Eileen McSaveney pers comm, 2015). 190 Prior to the earthquake sequence, stability of the loess during rain had been a major 191 focus of geotechnical investigation.

\section{MAFFEYS ROAD MASS MOVEMENT AREA}

194 One of the many mass movement sites identified in the loess mantled slopes of the 195 Port Hills was at Maffeys Road (Fig 3). The site morphology indicated that the slope 196 formed as an embayment along a now-abandoned sea cliff, with localised evidence of 197 past landslide scars. The slopes above the cliff are, for the most part, mantled by loess. 198

199 As noted earlier, previous studies suggested that one site was as good as any other site 200 for sampling loess in the Port Hills. Hence, ease of access for retrieval of heavy intact 201 samples and the known history of the site were the primary reasons for selecting the 202 Maffey Road site for sampling. The test results, however, revealed a high variability 203 of behaviour of intact samples from that one site, which may not have been evident if 204 we had chosen to sample from many sites.

206 Prior to the earthquake sequence there had been no large-scale slope deformation at 207 Maffeys Road since first European settlement (ca. 1840 AD); although a small earth 208 flow in the loess, caused by water from a pipe break, occurred in 2011 (Yetton and 
209 Engel 2014). No damage was reported at Maffeys Road following the 4 September 2010 earthquake, but cracks and other damage were found after the earthquakes of 22 February 2011 (Yetton and Engel 2014; Massey et al. 2014). The cracks indicated permanent slope displacement of about $0.5 \mathrm{~m}$ (Fig 2). Further small amounts of downslope movement were found following earthquakes on 13 June 2011 (c. $0.1 \mathrm{~m}$ ) and 22 December 2011 (c. $0.01 \mathrm{~m}$ ) (Massey et al. 2014).

A conceptual ground model (Fig 4) suggests that the loess mantling the Maffeys Road slope is similar to that found across much of the Port Hills (Massey et al. 2014). A thin layer of variable thickness of clayey silty gravel colluvium underlies the loess across much of the site. The colluvium is underlain by massive volcanic breccia with several flows of basalt lava. The lava breccia is weak to very weak with variable rock quality designation as low as 15\% (Yetton and Engle 2014). An interpretation of the bedrock surface suggests an overall dip of approximately $16^{\circ}$ towards the south-east; approximately coincident with the surface slope aspect (Massey et al. 2014). There is no evidence of instability in the units below the interface with the loess at this site.

\section{METHODOLOGY}

A suite of laboratory tests was used to determine the geotechnical characteristics of the loess from the Maffeys Road site. The experiments comprised a series of standard multi-stage loaded torsional ring shear tests on remoulded samples together with direct shear tests on both remoulded and undisturbed samples to establish representative field-stress conditions designed to simulate horizontal seismic excitation in a saturated loess slope.

Samples were collected as large intact blocks from the exposed loess cliffs at the Maffeys Road site (Fig 3). Each block was hand excavated from the cliff to avoid disturbance and, then wrapped to maintain natural moisture content before being boxed to avoid damage during transport. Standard soil classification tests were undertaken to establish the loess physical properties (Table 1 and Fig. 5). Particle-size analyses (Fig. 5) confirms that that the loess is fine grained comprising of approximately 50\% Clay and $40-45 \%$ silt with the remaining faction consisting mostly fine and medium grained sand. The natural moisture content was measured at $9.1 \%$ (Table 1) and a plastic limit of $16 \%$; a liquid limit of $25 \%$ and plasticity index 
243 of $9 \%$ indicating it lies at the boundary between a low plasticity silt and clay (defined

244 in accordance with BS5930, 1981). These values are within the typical ranges

245 previously measured for loess within the Port Hills (Yetton, 1986; Glassey, 1986;

246 Tehrani, 1988; McDowell, 1989).

Ring-shear tests on remoulded loess samples were undertaken using a Bromhead-type

Wykeham Farrance ring shearbox. During testing, the normal and shear loads, and the displacement, were recorded using a Picologger ADC24 data logger.

Ring-shear specimens were prepared from the loess sample blocks and each sample was prepared tested following standardised procedures (BSI, 1990). Consolidation was carried out incrementally through the addition of weights to the 10:1 lever ratio loading arm. Following consolidation, a slow shear rate of $0.0178 \mathrm{~mm} / \mathrm{min}$ was applied to ensure no excess pore pressure was generated during shear.

Shearing was multi-stage at three normal stresses $(154,276$ and $521 \mathrm{kPa})$; shearing at each normal stress was continued until a constant shear stress was observed. In each case, primary consolidation was completed before shearing was initiated. After the shear phase at the maximum normal stress $(521 \mathrm{kPa})$, the normal stress was reduced back to $154 \mathrm{kPa}$ before shearing was repeated to obtain a comparison with initial loading.

273 The apparatus, which can function as both a conventional direct shear and back 274 pressured shear machine, uses $100 \mathrm{~mm}$ x $100 \mathrm{~mm}$ x $20 \mathrm{~mm}$ samples. The machine

A further series of both standard and dynamic soil tests was carried out under direct shear using a Dynamic Back-Pressured Shearbox (DBPSB) constructed by GDS Instruments Ltd. The DBPSB provides the opportunity to carry out both static and dynamic direct shear testing on soils whilst controlling back pressure and measuring pore water pressure in the sample. The DBPSB is conceptually based on a standard direct shear device, but modified to allow the measurement and control of pore pressures and dynamic application of normal stress and shear stress (Fig. 6). provides both static and dynamic control of: horizontal (shear) and axial (normal) 
276 force and displacement; total stress; and effective stress. Sample pore water pressure can be monitored.

The DBPSB comprises both an upper and lower section of the sample vessel which is assembled using connecting screws. The lower section of the sample vessel contains a porous plate that is placed into a lower circular recess. Soil samples are placed into the sample vessel with filter papers of the same dimensions placed on the upper and lower sides of the sample. The sample vessel is then securely mounted in a sealed pressure vessel, an upper porous plate is placed on top of the specimen and vertical spacer is placed on the sample vessel after the connection screws have been removed. The vessel is sealed by the upper section of the DBSB apparatus using fastening screws. The load cell fits directly onto the upper porous plate. A vertical rod is connected to the apparatus and can apply a normal load to the sample, which is controlled by a hydraulic pressure controller.

The pressure vessel is flooded with de-aired water, and fluid pressure within the chamber is measured using two transducers, one mounted on a line that terminates adjacent to the sample, and the other on the fluid pressure control line.

The system is controlled and data logged using the GDSLAB control software, designed and developed by GDS, which runs on a standard PC.

The DBPSB was initially used for a standard shear-box test on an undisturbed sample (SB1) at a confining pressure of $148 \mathrm{kPa}$. To replicate the testing conditions on the remoulded ring shear tests, the sample was initially saturated by filling the shear box cell with water and then applying staged normal loads of 154, 276 and $521 \mathrm{kPa}$. Once consolidation was achieved a standard shear test was undertaken at a strain rate of $0.01 \mathrm{~mm} / \mathrm{min}$.

Other undisturbed loess samples were initially saturated in the DBSB to replicate samples below the groundwater table. Pore air pressures were eliminated by flushing the sample with carbon dioxide at a slow, controlled rate, before de-aired water was

308 flushed into both the shear box and sample to fill the pore air voids and ensure each 309 sample was fully saturated. Once saturation was complete, the back pressure and 
normal stress were simultaneously progressively ramped to $240 \mathrm{kPa}$ and $250 \mathrm{kPa}$ over

311120 minutes to dissolve any remaining carbon dioxide into solution in the sample.

312 During this period the normal stress was always kept $10 \mathrm{kPa}$ higher than the back 313 pressure to maintain a small positive normal effective stress and to prevent sample 314 swelling during the saturation process.

316 Sample consolidation was undertaken by applying a normal stress, as in an oedometer or standard direct shear test. A normal effective stress of $150 \mathrm{kPa}$ was applied, to replicate field conditions, by reducing back pressure to $100 \mathrm{kPa}$ whilst holding a total

338 To analyse the impacts of the frequency of seismic excitation, four samples (DYN1 to 339 DYN4) were subjected to dynamic shear phases for a period of 60 seconds at 340 frequencies ranging from $1 \mathrm{~Hz}$ (60 dynamic cycles) to $4 \mathrm{~Hz}$ (240 dynamic cycles). As 341 each test was subject to displacement- controlled shear, the key measured parameter is 342 shear strength. To assess the impact of repeated dynamic cycles, one sample (DYN5) 343 was subjected to 10 individual dynamic shear stages at a frequency of $2 \mathrm{~Hz}$ for a 
344 period of 1 minute each, at intervals of 10 minutes. One test (DYN6) was undertaken to assess the impact of long-duration seismic excitation on the shear surface. During this test, the sample was subject to a $2 \mathrm{~Hz}$ dynamic shear phase for a period of 10 minutes. The same test was then conducted on a remoulded loess sample (DYN7) to assess the variability in intact and remoulded behaviour.

\section{RESULTS}

A consolidation curve for the multi-stage ring-shear test (RS1) was constructed from incremental loadings to a final initial confining pressure of $154 \mathrm{kPa}$ (Fig 7 a). As anticipated, the sample experienced an increase in vertical strain through time to 4.6 $\%$. Incremental loading was also used to consolidate sample SB1 in the DPBSB (Fig 7 b) which increased vertical strain of $9.7 \%$. Sample SB2 was subject to a single loading phase and showed similar consolidation behaviour with an increase in vertical strain of $8.6 \%$ (Fig 7 b).

Consolidation curves of the DBPSB tests were constructed at a normal effective stress of $150 \mathrm{kPa}$. The results show some variability in behaviour between samples, with a trend of increasing vertical strain through time (Fig 7 c). DBPSB samples consolidated to vertical strains of between $5.5 \%$ and $6.5 \%$ at $150 \mathrm{kPa}$.

The shear behaviour in the ring shear test (RS1) showed consistent ductile behaviour during each loading cycle, with shear stress increasing to a near constant stress at each stage (Fig 8 a). Both the undrained and drained shear-box tests carried out in the DBPSB also showed (Fig 8 b) similar behaviour to the ring-shear test. In both tests, shear stress began to plateau at approximately $10 \%$ shear strain, although higher stresses were measured in the drained test. In both tests, a slight increase in shear stress was then observed with increasing strain, although this change in stress was more significant in undrained shear test (SB2) when a constant back pressure was maintained throughout shear.

The multi-staged ring-shear tests were used to calculate Mohr-Coulomb parameters and indicated a drained angle of internal friction of $27^{\circ}$ and cohesion of $6 \mathrm{kPa}$, which was consistent within error with both the standard direct drained and undrained shear tests in the DBPSB (Fig 8 c). These strength-envelope characteristics lay within the 
range of other values calculated using direct-shear and ring-shear tests for other loess from near Christchurch (Bell et al. 1986; Goldwater 1990; Carey et al. 2014).

The initial shear stage indicated significant variation in strength characteristics between samples (Fig 9 a), due to micro-scale variability in the structure of the loess. Whilst samples DYN5 and DYN6 achieved similar shear stress of 40 and $45 \mathrm{kPa}$ respectively at $2.5 \%$ shear strain, all other samples demonstrated shear stresses ranging from $25 \mathrm{kPa}$ to $33 \mathrm{kPa}$ at the same shear-strain level. Sample DYN1 underwent a loss of shear stress at the end of the test when $2.5 \%$ strain was achieved, reducing to $22 \mathrm{kPa}$ whilst strain was held constant. Each sample generated a relatively consistent pore-water pressure during the initial shear stage (Fig 9 b).

The horizontal displacement was accurately controlled by the DNBPSB throughout each dynamic test (Fig 10 a) and subsequently the change reduction in shear stress (Fig $10 \mathrm{~b}$ ), development of pore-water pressure (Fig $10 \mathrm{c}$ ) and the relationship between shear strain and shear stress were recorded throughout each test. Given the complexity of behaviour, we present the results of each dynamic test in terms of porewater response, shear stress and normal effective stress by plotting these values at peak shear stress measured during each dynamic cycle (Fig 11).

In the first set of dynamic experiments (DYN1 - DYN4), shear stress was applied at a range of frequencies. The response of the samples was variable, with the $1-\mathrm{Hz}$ (DYN1) and 3-Hz (DYN3) samples displaying liquefaction and resultant high porewater pressures (Fig 11 a). In these tests, the stress paths reached the conventional strength envelope in the first cycle, and then progressively weakened as excess pore pressure was generated. Eventually, pore-water pressures peaked and started to decline (Fig $11 \mathrm{~b}$ ), which permitted the samples to strengthen, but in this case defining a second envelope with zero cohesion and a lower effective angle of internal friction.

The 2-Hz (DYN2) and 4-Hz (DYN4) samples, which were observed to be the weakest samples during the initial shear phase, showed slightly different behaviour. These samples also reached the conventional strength envelope in the first cycle, but then rapidly weakened. Sample DYN2 demonstrated behaviour in the early stage of the test that was similar to the liquefaction seen in samples DYN1 and DYN3, but a lower 
412 strength envelope appears to have been defined (Fig 11 a). Sample DYN4 also generated high pore-water pressure, although significantly more cycles were required to reach a peak pressure. As a consequence, liquefaction did not occur. It was noticeable that the pore pressure response was variable between the tests, for example sample DYN4 sustained a peak pore pressure whilst the other tests showed rapid pore pressure dissipation (Fig $11 \mathrm{~b}$ ).

To further explore this behaviour, a test was conducted in which a sample (DYN6) was subjected to $2-\mathrm{Hz}$ dynamic shear stress for 600 seconds (i.e. for a duration that was an order of magnitude longer than that in the former series of tests). In this case, the sample also showed liquefaction and progressive weakening along the conventional failure envelope (Fig 12 a), similar to samples DYN1 and DYN3. By the end of the experiments, the excess pore pressure had fully dissipated (Fig 12 b).

In a further experiment, sample (DYN5) was subjected to 10 discrete phases of dynamic shear at 2-Hz, which in sum amounted to the same number of cycles as in test (DYN6). As before, the sample displayed liquefaction in the first 60 cycles (Fig 13 a). In the second phase of 60 cycles, the sample attained a peak shear stress that was significantly lower than in the first phase, and then weakened through liquefaction and the generation of excess pore pressure. However, in each subsequent cycle thereafter, the sample reached successively higher peak strengths and a higher final strength value. By cycle 10, the sample no longer generated excess pore pressure and reached a peak strength that was greater than the original peak strength value (Fig $13 \mathrm{~b}$ ), suggesting sample strengthening as a result of densification.

One test was conducted on a remoulded sample (DYN7). This sample reached the peak-strength envelope in the first cycle (Fig 14 a), but then rapidly weakened without generating much increased pore pressure (Fig 14 b) in a style similar to sample DYN4. In subsequent cycles, the sample generated excess pore pressure with very little reduction in shear stress. Later in the test, the excess pore pressure dissipated; the inflection point appeared to coincide with the conventional peak-strength envelope. The sample weakened slightly as pore pressure dissipated. 
446 The loess samples tested in the suite of drained dynamic shear experiments showed somewhat variable behaviour, indicating complex mechanisms of deformation. Dynamic liquefaction was observed in some of the tests. In these cases, the conventional failure envelope was reached during the first dynamic cycle (Fig 15 a), and subsequent cycles led to a rapid development of excess pore pressure and a corresponding decrease in shear strength at a nearly constant sample volume (Fig 15 b), until the sample shear surface underwent dynamic liquefaction, causing the shear strength of the sample to drop below the conventional strength envelope. During this phase of deformation, the sample strength was no longer controlled by the frictional strength of the loess. During the collapse and flow phase, the pore water pressures dissipated whilst the sample volume continued to reduce, suggesting densification of the shear surface. As pore pressure dissipated, samples regained shear strength, although shear stresses remained significantly lower than the conventional failure envelope.

Intact samples subjected to many cycles (DYN6) of dynamic shear appeared to reach an ultimate critical state. Samples in this state no longer accumulated vertical strain and therefore deformed at constant volume (Fig 16).

Similar failure mechanisms were observed in a series of undrained and drained triaxial tests on sands (Sladen et al. 1985; Sasitharan et al. 1993). These studies concluded that liquefaction failures occur along a collapse surface in three dimensional void ratio - shear stress - normal stress space. This collapse concept was argued to be fundamentally an extension of critical state soil mechanics (Sladen et al. 1985). In addition, more recent laboratory studies (Wang et al. 2014) comprising undrained triaxial compression and ring-shear tests on remoulded loess demonstrate that water-saturated loess is highly susceptible to liquefaction and flow failure, whilst fast shear tests on dried, air-saturated loess generated only small pore air pressures and no significant reduction in shear resistance.

The weakest samples at $2 \mathrm{~Hz}$ and $4 \mathrm{~Hz}$ (DYN2, DYN4) and the remoulded 2-Hz 10 min (DYN7) tests showed different behaviour. In these tests, dynamic shear caused a more immediate decrease in sample volume (Fig 17 a). We hypothesise that because these samples were disturbed, their permeability, and therefore their ability to drain 
480 during dynamic shear may have been greater. As a consequence, excess pore water pressures were less likely to be generated at constant volume during the early stages of the test. In these cases, the samples show post-failure pore pressure generation, without further weakening. We further hypothesise that the dynamic shear and more gradual rise of pore pressures occurred as the damaged sample were able to drain faster than the intact samples. As a consequence, liquefaction and collapse did not occur, but instead the material deformed through a flow-type mechanism until pore pressures dissipated through sample densification (Fig $17 \mathrm{~b}$ ). In the case of the remoulded sample (DYN7) deformation at the end of the test reached a constant critical state (Fig 16). In these experiments it should be noted that the sample was returned to the same value of shear strain at the end of each cycle, such that a stress strain curve could not be generated.

We noted the different behaviour observed between the remoulded sample subjected to 600 seconds of dynamic shear stress at $2 \mathrm{~Hz}$ (DYN7) and that subjected to ten cycles of dynamic excitation (DYN5), each lasting 30 seconds, also at $2 \mathrm{~Hz}$. At the end of the tests, both samples had been subjected 600 cycles at the same frequency (2 $\mathrm{Hz}$ ). However, in sample DYN5, the excess pore pressure generated by the dynamic shear stress was allowed to dissipate prior to the start of the next cycle (Fig 18 a). In this case, the sample showed the same dynamic liquefaction behaviour during the first dynamic cycle as was observed in other intact sample tests (Fig 13 a). Subsequent cycles, however, showed an increase in density and as consequence pore water pressure and sample volume progressively reduced with each cycle (Figure 18 a). Thus, whilst a similar failure envelope was observed during the second cycle in sample DYN5 and the remoulded sample DYN7, indicating that liquefaction could no longer occur, repeat cycles successively strengthened sample DYN5 back toward the conventional failure envelope (Fig 18 b). These results suggested that successive periods of earthquake shaking may act to consolidate the loess, making liquefaction and instability less likely in future seismic events.

\section{CONCLUSION}

Mechanisms of failure in loess slopes during seismic excitation were studied through a series of dynamic shear tests using a newly developed dynamic back-pressured shear box (Model DBPSB of GDS Ltd). This new machine allows laboratory 
514 simulation of complex hillslope environments to study the nature and cause of earthquake-induced landslides. The study demonstrated that a saturated intact loess slope can fail during seismic excitation as a result of dynamic liquefaction of the shear surface (Sladen et al.1985).

In a saturated intact loess slope, sufficient dynamic shear may collapse the shear zone, creating a very rapid increase in pore water and rapid reduction in shear strength. Following failure, these excess pore pressures rapidly dissipate as water drains away. As a consequence, the shear zone consolidates and the shear strength increases until reaching a critical state. The final critical state during seismic excitation may have lower shear strength than the conventional residual strength envelope. This rapid reduction in mean normal effective stress is capable of generating rapid failures of slopes during earthquakes, as has been observed in a number of previous events (e,g. Wang et al. 2014).

In some instances, however, loess slopes with sufficiently small pore spaces, such as previously disturbed slopes or slopes in fine-grained or dense loess deposits can rapidly weaken during seismic excitation without failing through dynamic liquefaction. In these slopes, dynamic shear rapidly reduces shear strength but excess pore-water pressure is generated at a slower rate. Pore water pressures subsequently dissipate, allowing strengthening until reaching a critical state. Again, this final state during seismic excitation has lower shear strength than the conventional residual strength envelope. Whilst the reduction in strength and increase in pore pressure are likely to result in slope failure, the displacement rate of such failures may be significantly slower than observed from dynamic liquefaction.

Repeat cycles of dynamic excitation where excess pore pressure could dissipate between each dynamic stage suggest that following dynamic liquefaction, each successive phase of dynamic shear further consolidates the shear zone. As a consequence, pore-pressure generation is lower during successive cycles and both the dynamic shear strength and conventional strength envelope progressively increase. The results suggest that once initial failure of a loess slope occurs, successive earthquakes are unlikely to reduce the stability further and may indeed strengthen the slope. 
Although exceptional levels of ground shaking occurred during the Canterbury earthquake sequence, the results suggest that dynamic liquefaction probably did not occur in the type 1 loess landslides such as at Maffeys Road, which underwent relatively small displacements (e.g. total displacements in the order of millimetres) with little run-out. The geological characteristics of these slopes suggest they are relatively free-draining loess deposits that were relatively dry when seismically excited. As a consequence, if any collapse occurred, it did not develop sufficient excess pore pressure to drive dynamic liquefaction.

Failures seated in the type 2 loess landslides, however, where a water table was present in the loess, are likely to be susceptible to dynamic liquefaction. In these slopes, movement occurred at a variety of very low slope angles (approximately $15^{\circ}$ ) in loessial materials with angles of internal friction of about $30^{\circ}$. Their movement locally caused much damage to structures where there was surface deformation (shear, compression and extension), but much motion was as a series of nondeforming rafts.. Still these landslides had only limited total displacement, with most of it during the strong seismic activation, with little post-seismic creep.

\section{ACKNOWLEDGMENT}

The authors thank Chris Massey, Mark Yetton for information and advice. Christchurch City Council facilitated site access and provided data from boreholes and mapping studies. Zane Bruce and Mark Yetton assisted in the field sampling. Stuart Read and Peter Barker are thanked for their support during the laboratory testing and analysis phase which was undertaken within the GNS rock and soil mechanics laboratory. We also thank our GNS Science colleagues Will Ries and Darren D'Cruz who prepared the figures and Phil Glassey for his constructive review of an earlier draft of this manuscript. The research has in part been supported by the GNS Science Strategic Development Fund, the GNS direct crown funded Landslide Hazards Programme and by the NERC/ESRC Increasing Resilience to Natural Hazards programme under the Earthquakes Without Frontiers project, grant reference NE/J01995X/1 and NERC/Newton Fund grant NE/N000315.REFERENCES 
580 Bannister SC, and Gledhill KR (2012) Evolution of the 2010-2012 Canterbury earthquake sequence. New Zealand Journal of Geology and Geophysics, $\quad$ 55(3): 295304.

583 Bell DH, Glassey PJ, Yetton MD (1986) Chemical stabilisation of dispersive loessical soils, Banks Peninsula, Canterbury, New Zealand. Proceedings of the 5th International Congress of the International Engineering Geological Society, 1: 21932208

588

Bell DH, Trangmar BB (1987) Regolith materials and erosion processes on the Port Hills, Christchurch, New Zealand: Fifth International Symposium and Field Workshop on Landslides. Lausanne, A.A. Balkema. Volume 1: 77-83.

Brain MJ, Rosser NJ, Sutton J, Snelling K, Tunstall N, Petley DN (2015) The effects of normal and shear stress wave phasing on coseismic landslide displacement. Journal of Geophysical Research: Earth Surface. 120, 1009-1022.

Brown LJ, Weeber JH (1992) Geology of the Christchurch urban area. Scale 1:25,000. Institute of Geological \& Nuclear Sciences geological map. 1.

British Standards Institute (BSI) (1981) Code of Practice for Site Investigations. BS 5930: 1981.

British Standards Institute (BSI) (1990) British standard methods of test for soils for civil engineering purposes. Part 1: General requirements and sample preparation. BS 1377: Part 1.

Carey JM, Misra S, Bruce Z, Barker P (2014) Canterbury Earthquakes 2010/2011 Port Hills Slope Stability: Laboratory Testing Factual Report. GNS Science Consultancy Report.2014/53.

Castro G, Enos JL, France JW, Poulos SJ (1982) Liquefaction induced by cyclic loading. National Science Foundation NSF/CEE-82018.

Cruden DM, Varnes DJ (1996) Landslides types and processes. In: Turner AK, Schuster RL (eds) Landslides Investigation and Mitigation: Transportation Research Board. US National Research Council, Washington, DC, pp 36-75 Special Report 247.

Dellow G, Yetto M, Massey CI, Archibald GC, Barrell DJA, Bell D, Bruce Z, Campbell A, Davies T, De Pascale G, Easton M, Forsyth PJ, Gibbons C, Glassey PJ, Grant H, Green R, Hancox GT, Jongens R, Kingsbury P, Kupec J, Macafarlane D, McDowell B, McKelvey B, McCahon M, McPherson I, Molloy J, Muirson J, O'Hallaran M, Perrin ND, Price C, Read SAL, Traylen N, Van Dissen RJ, Villeneuve 
614 M, Walsh I (2011) Landslides caused by the 22 February 2011 Christchurch earthquake and management of landslide risk in the immediate aftermath, Bulletin of the New Zealand Society for Earthquake Engineering. 44(4): 227 - 238. Della Pasqua F, Massey C I, Lukovic B, Ries W, Archibald G, Heron D (2014) Canterbury Earthquakes 2010/11 Port Hills Slope Stability: Risk assessment for Maffeys Road. GNS Science Consultancy Report 2014/79.

Evans SG, Roberts NJ, Ischuk A, Delaney KB, Morozova GS, Tutubalina O (2009) Landslides triggered by the 1949 Khait earthquake, Tajikistan, and associated loss of life. Engineering Geology, 109 (3-4): 195 - 212.

Fletcher L, Hungr O, Evans SG (2002) Contrasting failure behaviour of two large landslides in clay and silt. Canadian Geotechnical Journal, 39 (1): 46-62.

Glassey PJ (1986) Geotechnical Properties of Lime Stabilised Loess, Port Hills Canterbury. Unpublished MSc thesis, University of Canterbury.

Gledhill K, Ristau J, Reyners M, Fry B, Holden C (2011) The Darfield (Canterbury, New Zealand) Mw 7.1 earthquake of September 2010: A preliminary seismological report. Seismological Research Letters. 82 (3), 378-386.

Griffiths E (1973) Loess of Banks Peninsula. New Zealand Journal of Geology and Geophysics, 16: 657 - 675.

Kaiser A, Holden C, Beavan J, Beetham D, Benites R, Celentano A, Collett D, Cousins J, Cubrinovski M, Dellow G, Denys P, Fielding E, Fry B, Gerstenberger M, Langridge R, Massey C, Motagh M, Pondard N, McVerry G, Ristau J, Stirling M, Thomas J, Uma SR, Zhao J (2012) The Mw 6.2 Christchurch earthquake of February 2011: preliminary report. New Zealand Journal of Geology and Geophysics, 55 (1): $67-90$.

Massey CI, Yetton MJ, Carey JM, Lukovic B, Litchfield N, Ries W, McVerry G (2013) Canterbury Earthquakes 2010/11 Port Hills Slope Stability: Stage 1 report on the findings from investigations into areas of significant ground damage (assessed source areas). GNS Science Consultancy Report, 2012/317.

Massey CI, Della Pasqua F, Lukovic B, Ries W, Heron D (2014) Canterbury Earthquakes 2010/11 Port Hills Slope Stability: Risk assessment for Cliff Street. GNS Science Consultancy Report, 2014/73.

Massey C, McSaveney M, Taig T, Richards L, Litchfield N, Rhoades D, McVerry G, Lukovic B, Heron D, Ries W, Van Dissen R 2014. Determining rockfall risk in 
647 Christchurch using rockfalls triggered by the 2010/2011 Canterbury earthquake sequence, New Zealand. Earthquake Spectra, 30: 155-181.

McDowell BJ (1989) Site investigations for residential development on the Port Hills, Christchurch, M.Sc. thesis (unpublished). University of Canterbury.

McRoberts EC, Sladen JA (1992) Observations on static and cyclic sand liquefaction methodologies. Canadian Geotechnical Journal, 29: 605 - 665.

Raeside JD (1964) Loess Deposits of the South Island, New Zealand, and Soils formed on them. New Zealand Journal of Geology and Geophysics, 7: 811 - 838.

Ristau J, Holden C, Kaiser AE, Williams CA, Bannister SC, Fry B (2013) The Pegasus Bay aftershock sequence of the $M_{w} 7.1$ Darfield (Canterbury), New Zealand earthquake. Geophysical Journal International,195(1): 444 - 459.

Goldwater S (1990) Slope failure in loess. A detailed Investigation, Allendale, Banks Peninsula. MSc Thesis (unpublished), University of Canterbury.

Runqiu H, (2009) Some catastrophic landslides since the twentieth century in the southwest of China. Landslides, 6: 69-81.

Sasitharan S, Robertson PK, Sego DC, Morgenstern NR (1993) Collapse behaviour of sand. Canadian Geotechnical Journal, 30: 569 - 577.

Seed HB (1966) Landslides during earthquakes due to soil liquefaction. J. Soil. Mech.Found. Div. ASCE 94, (5), 1055-1122.

Sladen JA, D'Hollender RD, Krahn J (1985) The liquefaction of sands a collapse surface approach. Canadian Geotechnical Journal, 22(4): 564-578.

Tehrani BH (1988) Chemical Stabilistaion of Whaka Terrace Loess. Unpublished MSc thesis, University of Canterbury.

Ter-Stepanian G (1998) Suspension force induced landslides. Proceedings of 8th Congress of IAEG, Vancouver, Canada. Balkema, Rotterdam, 3, p.1905-1912. Varnes, D.J. 1978. Slope movement types and processes In: Schuster RL, Krizek RJ (eds) Landslide Analysis and Control, National Academy Sciences, Transportation Research Board Spec Rep 176:11-33.

Wang G, Zhang D, Furuya G, YangJ (2014) Pore-pressure generation and fluidization in a loess landslide triggered by the 1920 Haiyuan earthquake, China: A case study. Engineering Geology, 174: 36-45.

Wang G, Sassa K (2002) Post-failure mobility of saturated sands in undrained load controlled ring shear tests. Canadian Geotechnical Journal, 39: 821-837. 
680 Wang G, Sassa K, Fukuoka H, Tada T (2007) Experimental study on the shearing

681 behavior of saturated silty soils based on ring shear tests. Journal of Geotechnical and 682 Geoenvironmental Engineering. ASCE 133 (3), 319-333.

683 Xu L, Dai F, Tu X, Tham GT, Zhou Y, Iqbal J (2013) Landslides in a loess platform, 684 North-West China. Landslides. DOI 10.1007/s10346-013-0445-X

685 Yetton MD (1986) Investigation and Remedial Methods for Subsurface

686 Erosion Control in Banks Peninsula Loess. MSc Thesis (Unpublished),

687 University of Canterbury.

688 Yetton MD, (1992) Engineering geological and geotechnical factors affecting 689 development on Banks Peninsula and surrounding areas - Field guide. Bell, D.H. 690 (ed.): Landslides - Proceedings of the Sixth International Symposium, Christchurch, 691 10-14 February 1992, Rotterdam, A.A. Balkema, Vol. 2(3).

692 Yetton M, Engel M (2014) Port Hills Land Damage Studies Maffeys Road Field Investigations. URS Limited report for Christchurch City Council

694 Wen B, Wang S, Wang E, Zhang J (2004) Characteristics of rapid giant landslides in 695 China. Landslides, 1: $247-261$.

696 Zhang D, Sassa K (1996) Study of the mechanism of loess landslides induced by

697 earthquakes. J. Jpn. Soc. Erosion Control Eng. 49: 4-13 (in Japanese).

698 Zhang D, Takeuchi A, Sassa K (1995) The motion characteristics of loess landslides 699 induced by the Haiyuan earthquake in Ningxia Province, China. J. Jpn. Landslide Soc. $70032(1), 12-17$ (in Japanese).

701 Zhang FY,Wang G, Kamai T, Chen WW, Zhang DX, Yang J (2013) Undrained shear 702 behaviour of loess saturated with different concentrations of sodium chloride solution. 703 Engineering Geology, 155, 69-79.

704 Zhang D, Wang G, (2007) Study of the 1920 Haiyuan earthquake-induced landslides 705 in loess (China). Engineering Geology, 94: 76-88.

706 Zou JS, Shao SM (1996) Landslides induced by Haiyuan earthquake and their 707 distribution (in Chinese). Cont Earthquake, 10:1-5 (in Chinese). 
709

710

711

712

713

714

715

716

717

718

719

720

721

722

723

724

725

726

727

728

729

730

731

732

733

734

735

736

737

738

739

740

741

\section{FIGURES}

Figure 1. Site location of the Canterbury Port Hills New Zealand.

Figure 2. Typical loess landslide types identified during the 2010-2011 Canterbury earthquake sequence (a) Morphology of Type 1 failures form loess overlying bedrock (b) Conceptual model of Type 1 failures completely within loess (c) Conceptual model of Type 1 failures of loess along subsurface interface (d) Morphology of Type 2 failures of loess toe slumps (e) Conceptual model of Type 2 failures of loess toe slumps.

Figure 3. The Maffeys Road study site (a) Maffeys Road mass movement extent based on surface deformation mapping and block sampling location (b) damage associated with earthquake-induced ground movements at Maffeys Road and (c) sampling of exposed loess slopes.

Figure 4. Maffeys Road ground model (adapted from Massey et al. 2014 and Yetton and Engel 2014).

Figure 5. The particle size distribution of the loess sampled at Maffeys Road.

Figure 6. Schematic diagram of the Dynamic Back-Pressured Shear box testing apparatus.

Figure 7. Loess consolidation characteristics (a) Multi-stage ring shear test (b) Conventional drained (SB1) undrained (SB2) direct shear tests in the BPSB (c) DBPSB testing.

Figure 8. Loess shear strength characteristics from Maffeys Road using (a) multistage ring shear testing and (b) drained (SB1) and undrained (SB2) direct shear testing in the DBPSB (c) failure envelope constructed from multi-stage ring shear test compared to shear strength characteristics observed in the undrained and drained direct shear tests in the DBPSB. 
742 Figure 9. Initial shear stage characteristics of DBPSB testing (a) shear stress against strain and (b) Pore water pressure against shear strain.

Figure 10. Sample DYN2 dynamic strain controlled shear results (a) horizontal displacement against time (b) shear stress against time (c) pore water pressure against time (d) shear strain against shear stress.

Figure 11. Dynamic shear stage of testing at frequencies of 1, 2, 3 and $4 \mathrm{~Hz}$ for a duration of 1 minute (a) pore water pressure against cycle number and (b) shear stress against normal effective stress.

Figure 12. Dynamic shear stage of testing at a frequency of $2 \mathrm{~Hz}$ for a duration of 10 minutes on an intact sample (a) pore water pressure against cycle number and (b) shear stress against normal effective stress.

Figure 13. Dynamic shear stage of testing at a frequency of $2 \mathrm{~Hz}$ for 10 cycles of 1 minute duration (a) pore water pressure against cycle number and (b) shear stress against normal effective stress.

Figure 14. Dynamic shear stage of testing at a frequency of $2 \mathrm{~Hz}$ for a duration of 10 minutes on a remoulded sample (a) pore water pressure against cycle number and (b) shear stress against normal effective stress.

Figure 15. Dynamic shear stage of samples undergoing dynamic liquefaction (a) shear stress against normal effective stress (c) Pore water pressure against change in sample volume.

Figure 16. Change in sample height of intact sample DYN6 and remoulded sample DYN7 during the dynamic shear stage of testing at a frequency of $2 \mathrm{hz}$ for a duration of 10 minutes (1200 cycles).

Figure 17. Dynamic shear stage of samples not undergoing dynamic liquefaction (a) shear stress against normal effective stress (c) Pore water pressure against change in sample volume. 
1

777 Figure 18. Dynamic shear stage of remoulded sample DYN7 and post dynamic

778 liquefaction repeat cycles of sample DYN5 (a) Pore water pressure against vertical 779 strain (b) Shear stress against normal effective stress.

780

781 TABLES

782 Table 1. Loess physical properties

783 Table 2. Summary of laboratory tests. 


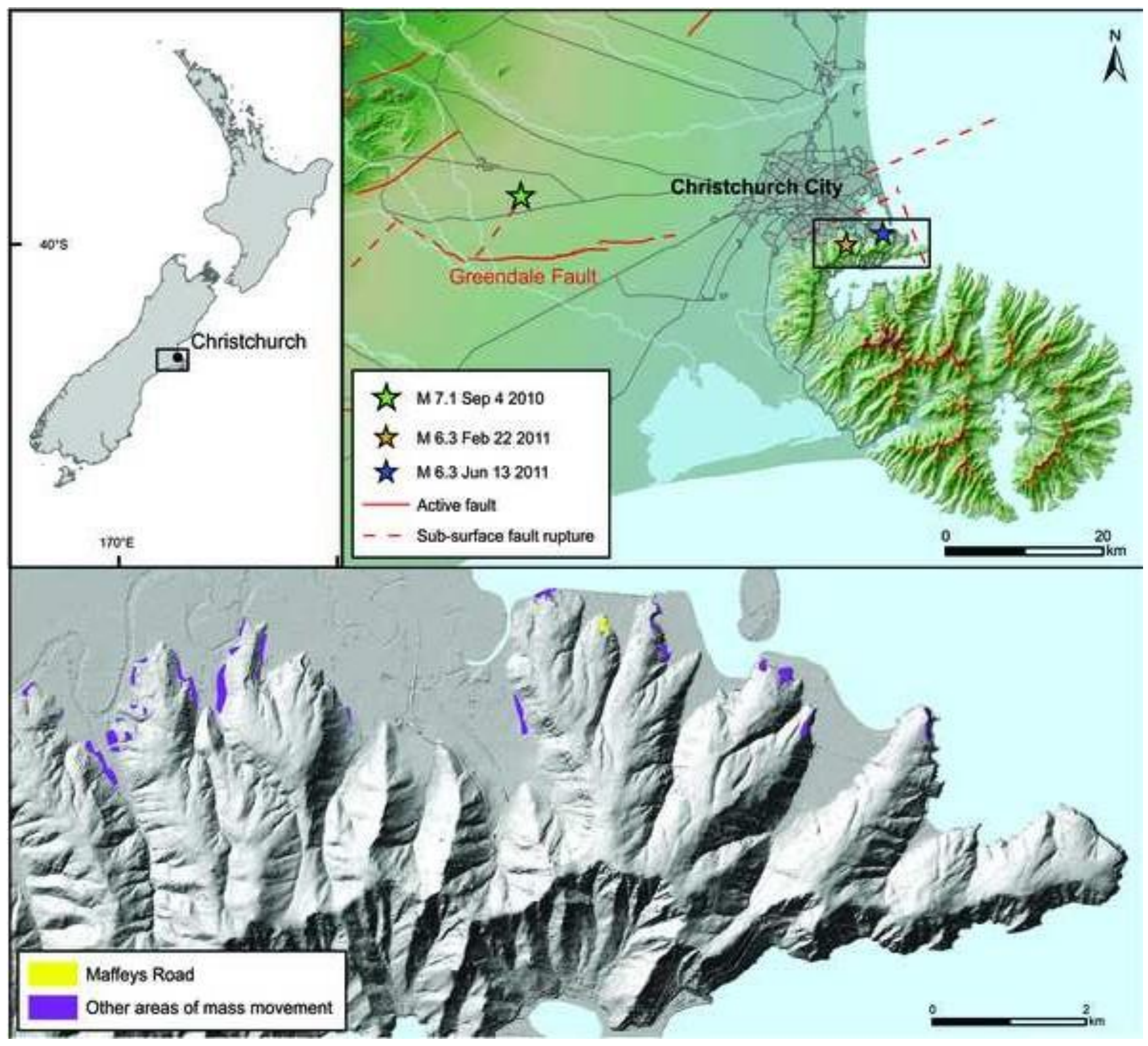



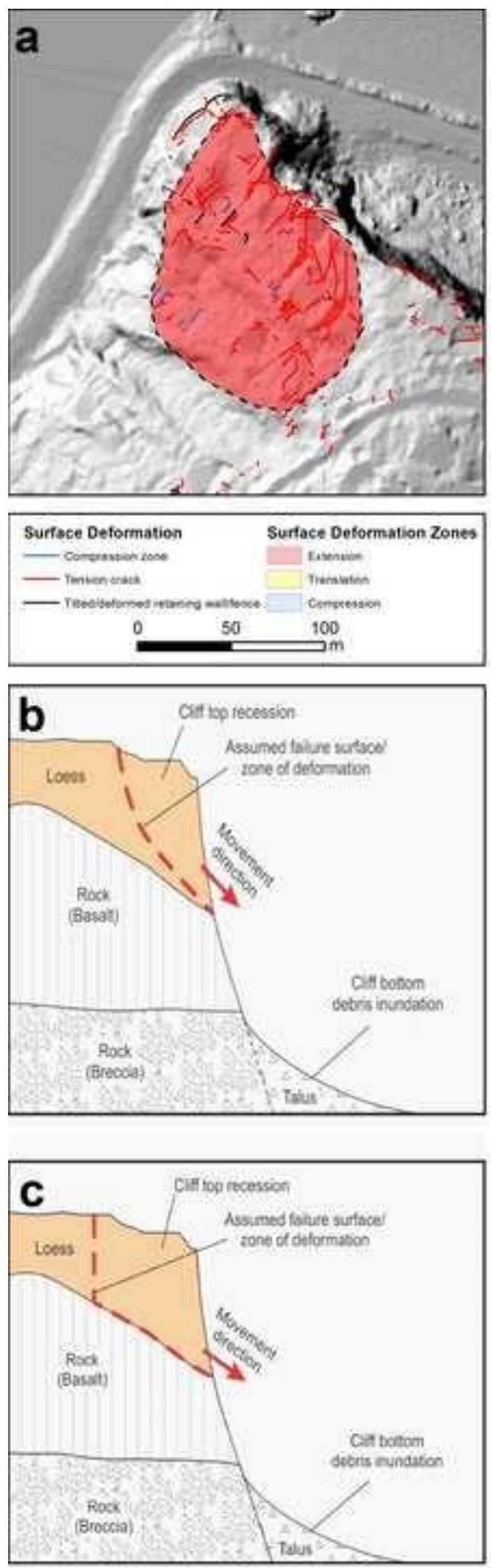

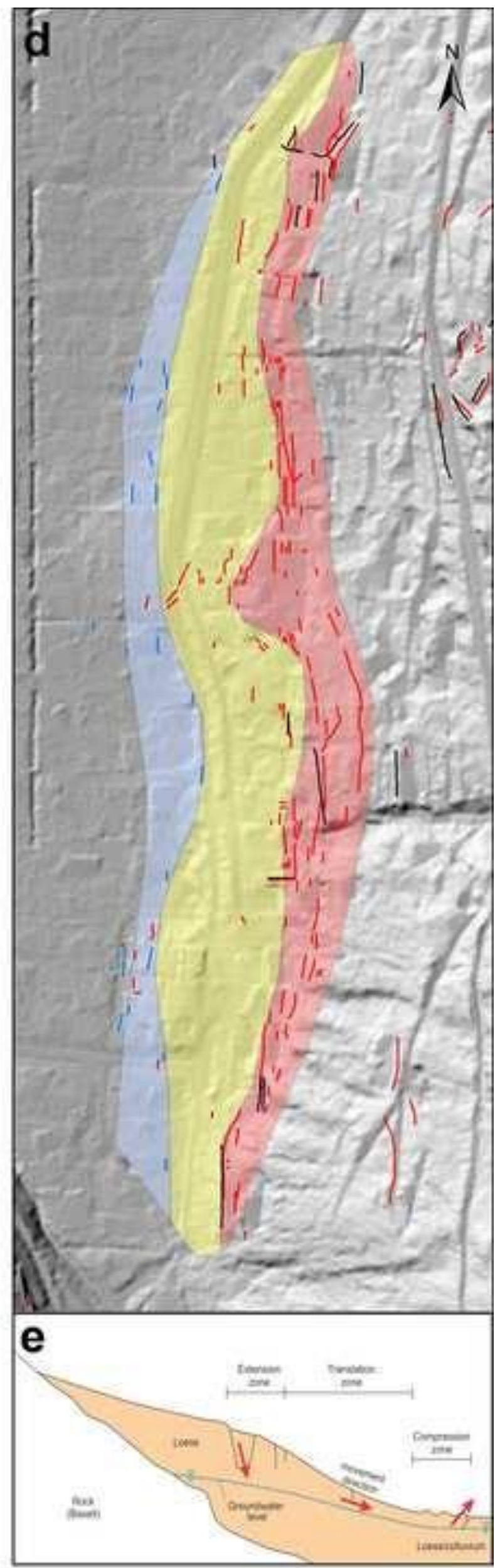



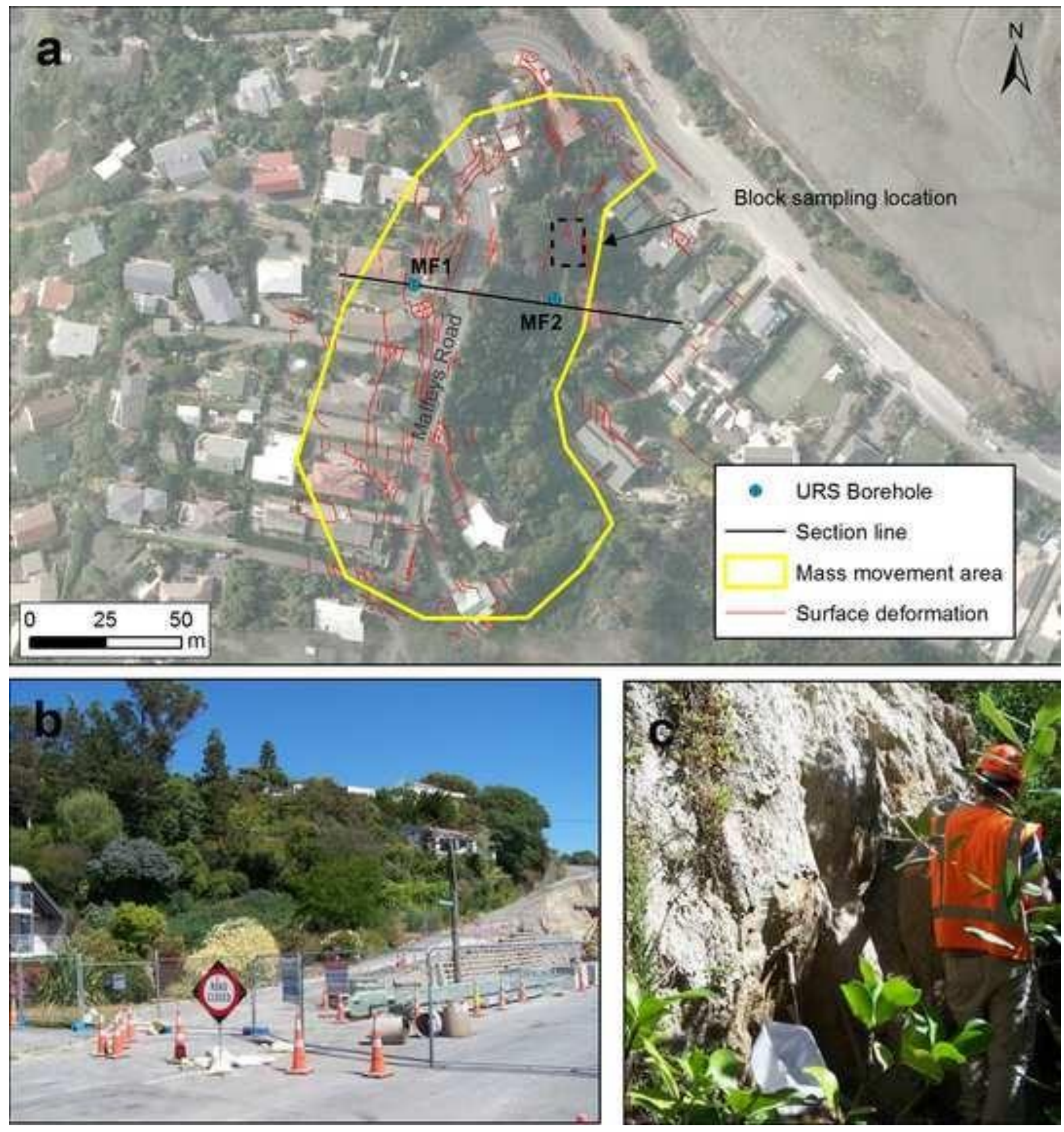


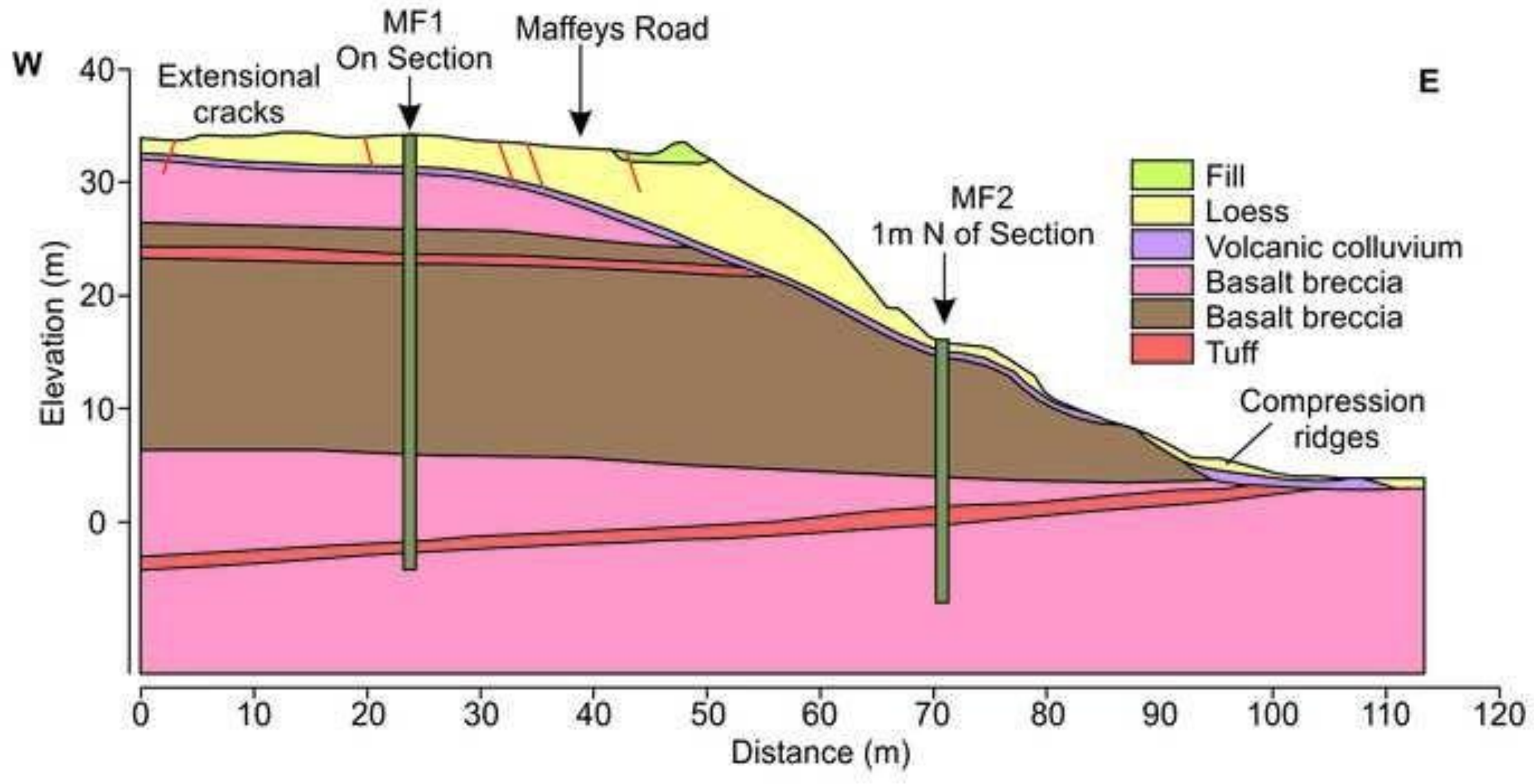




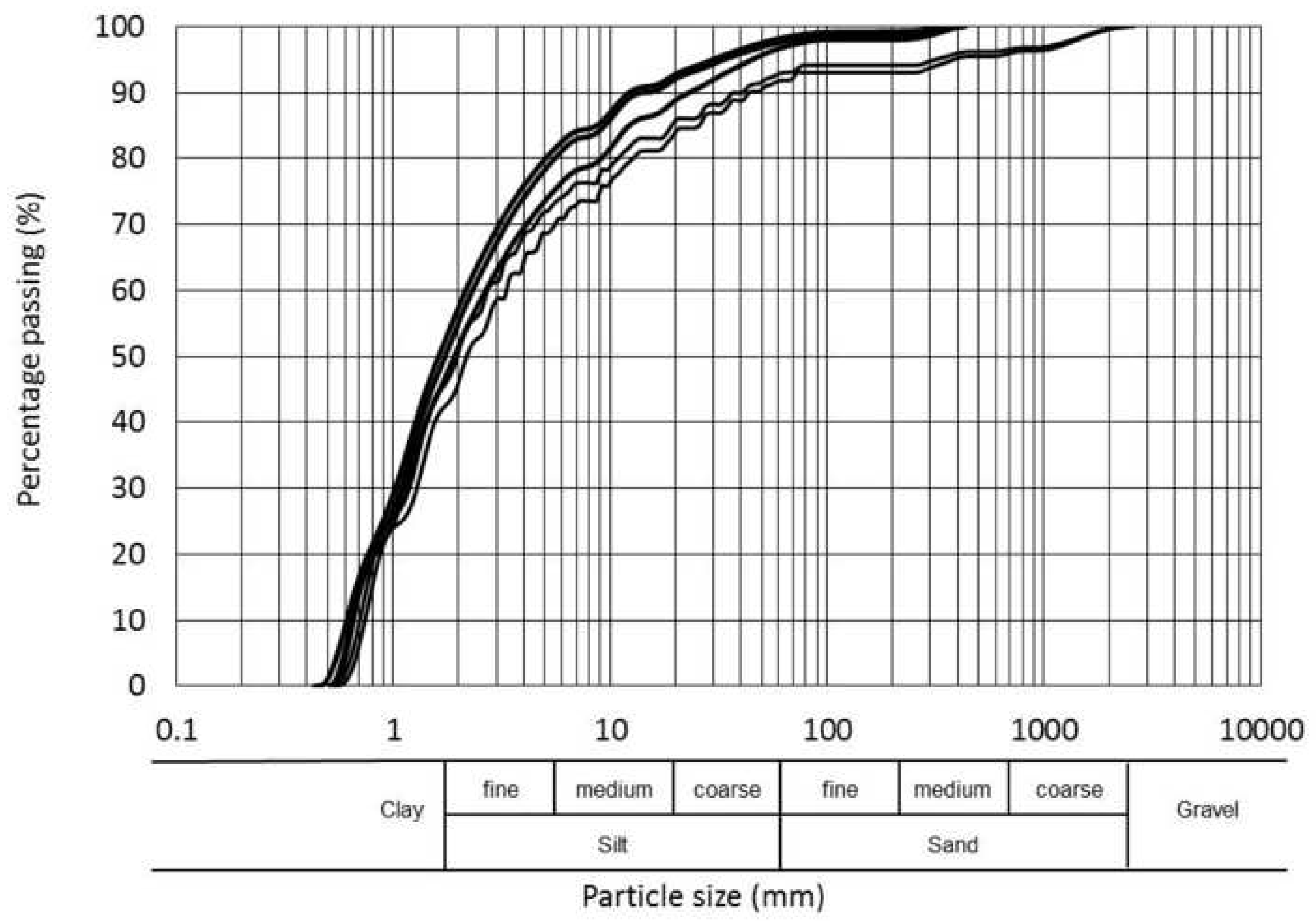




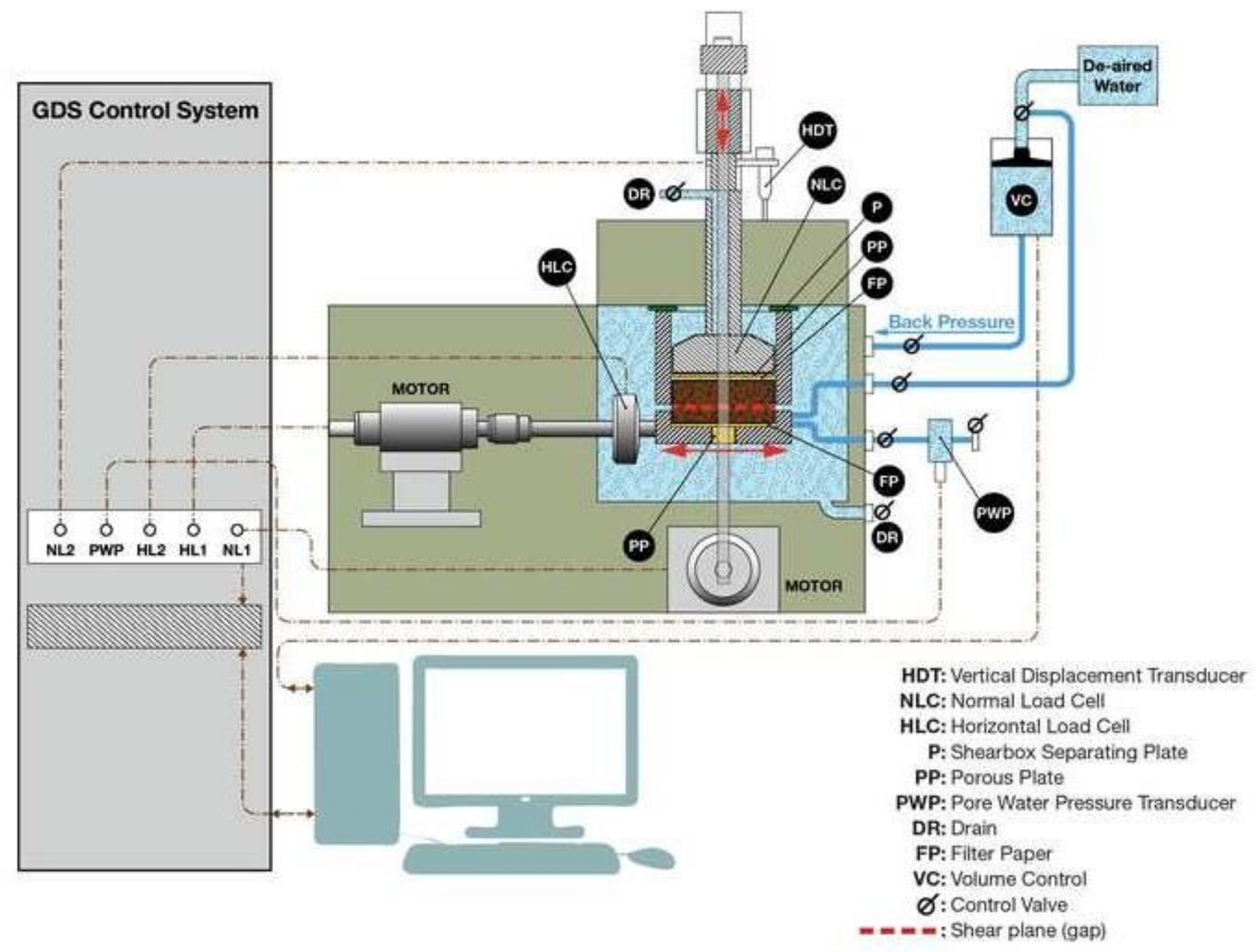




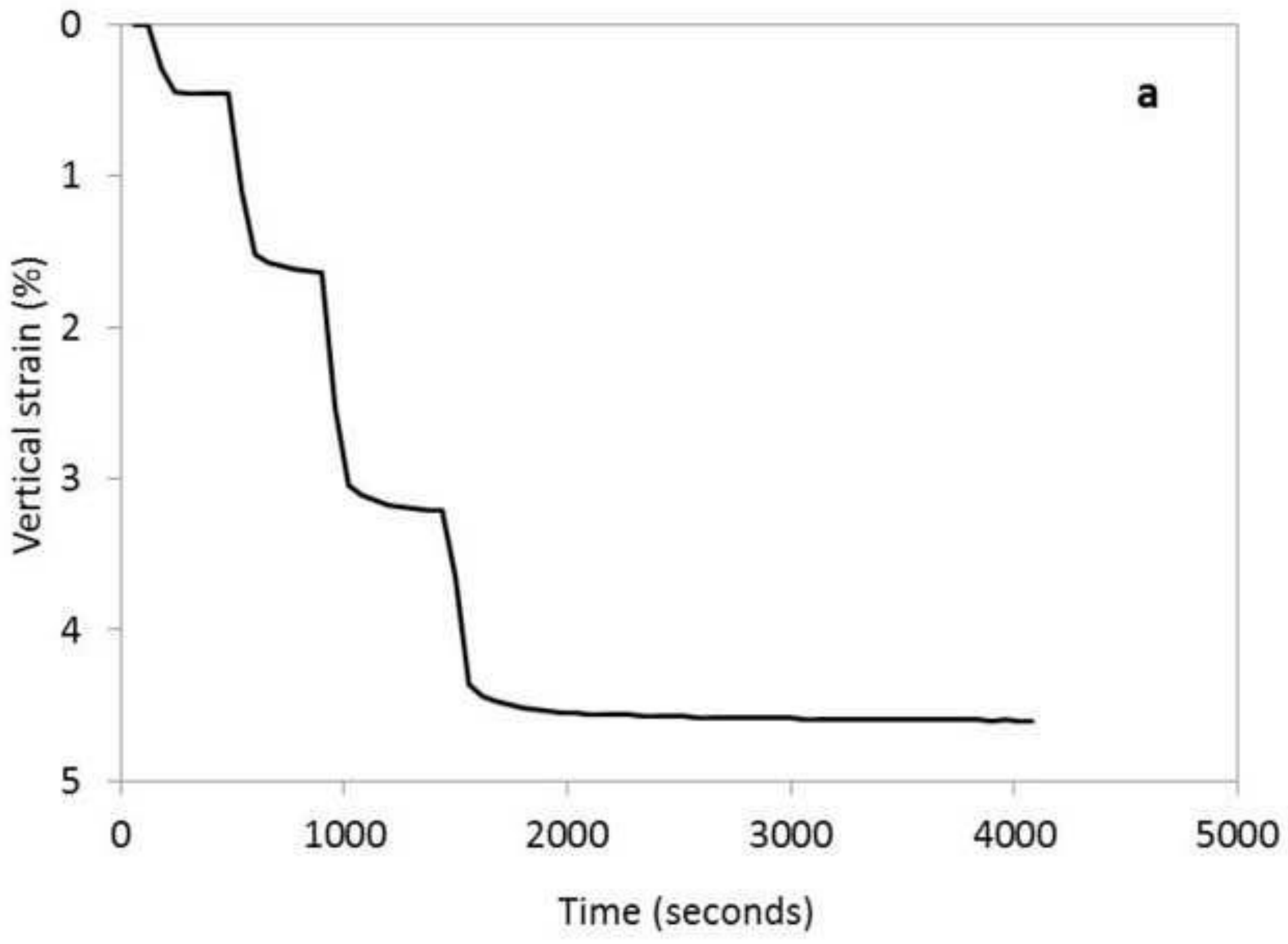




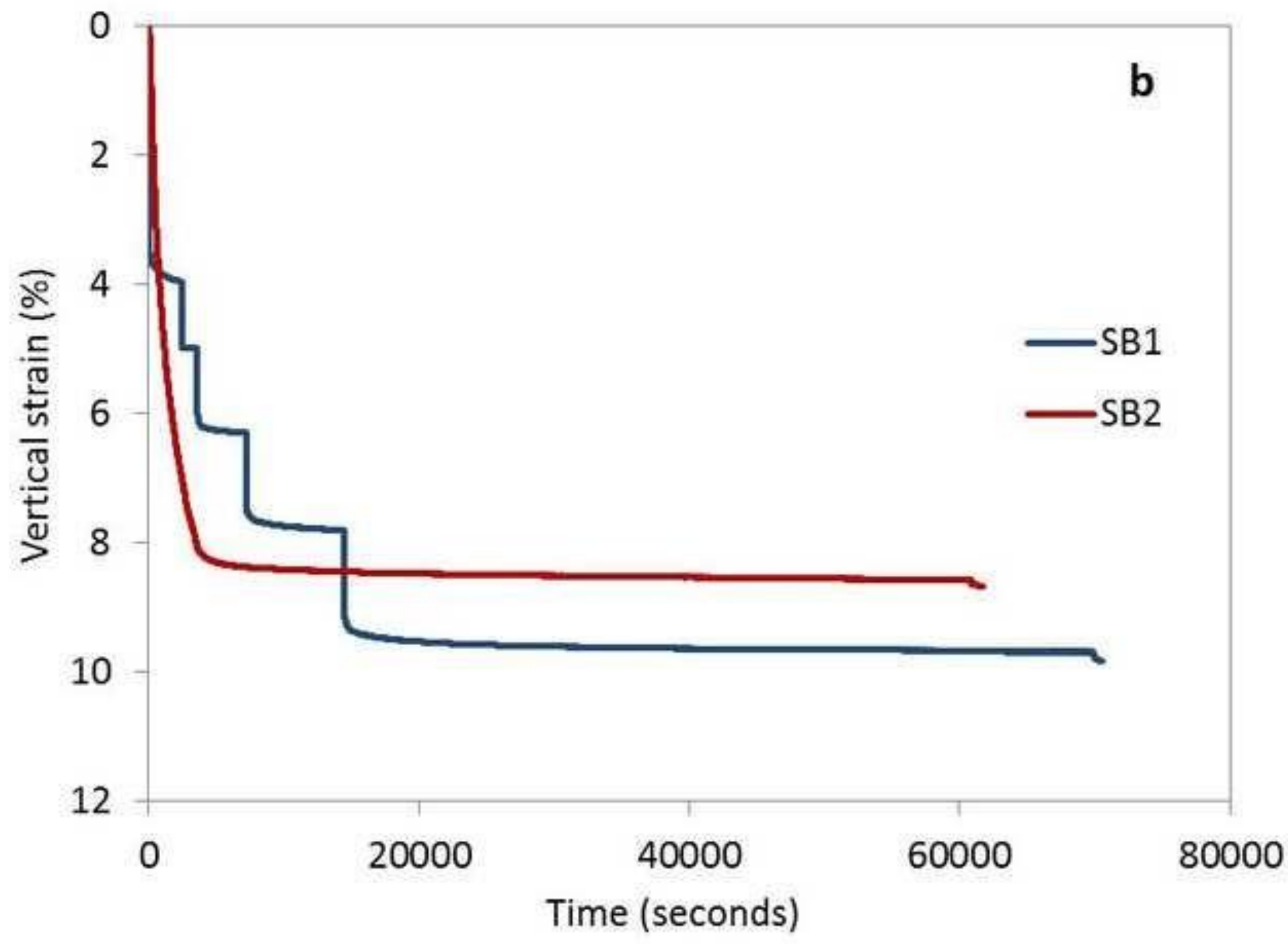




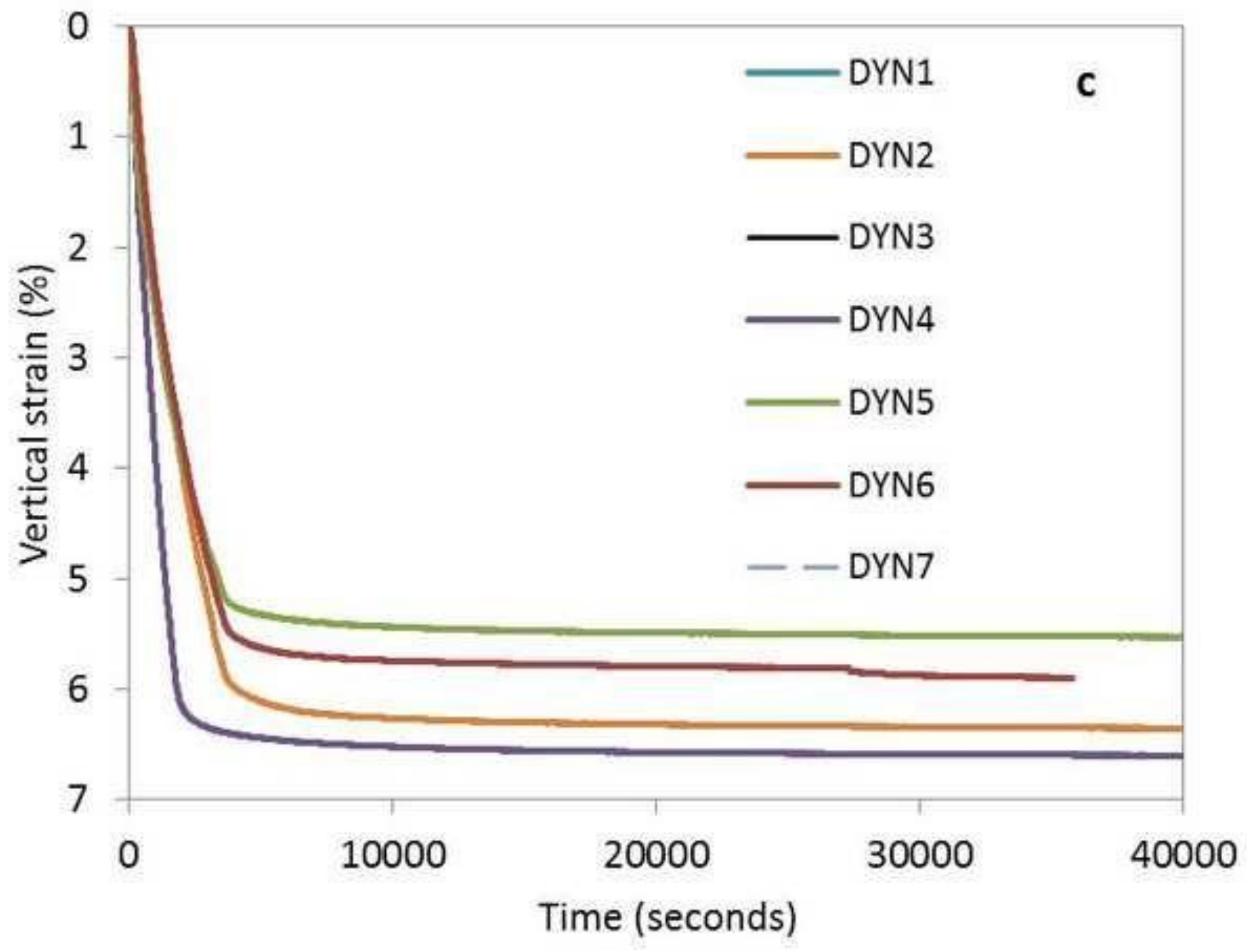




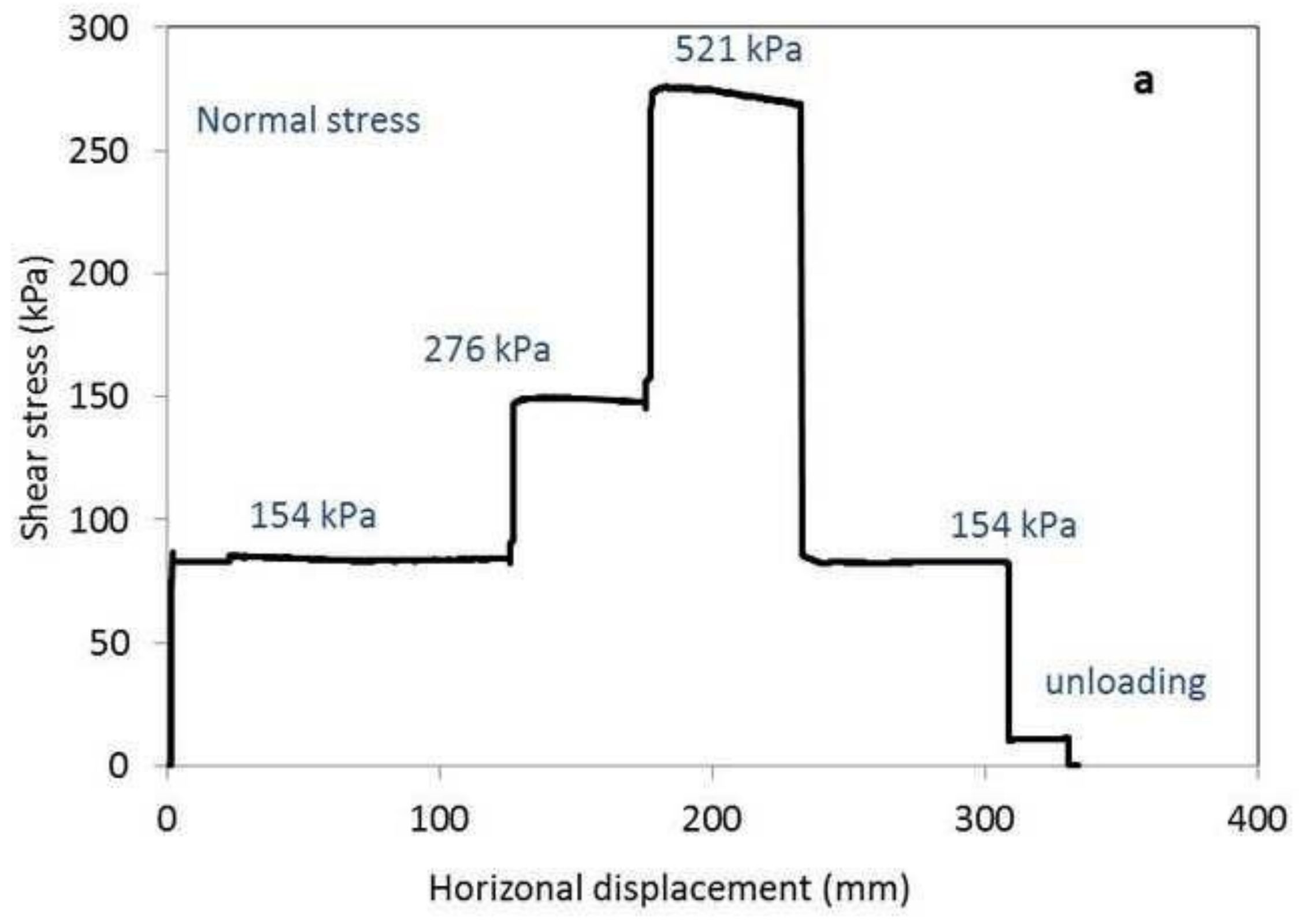




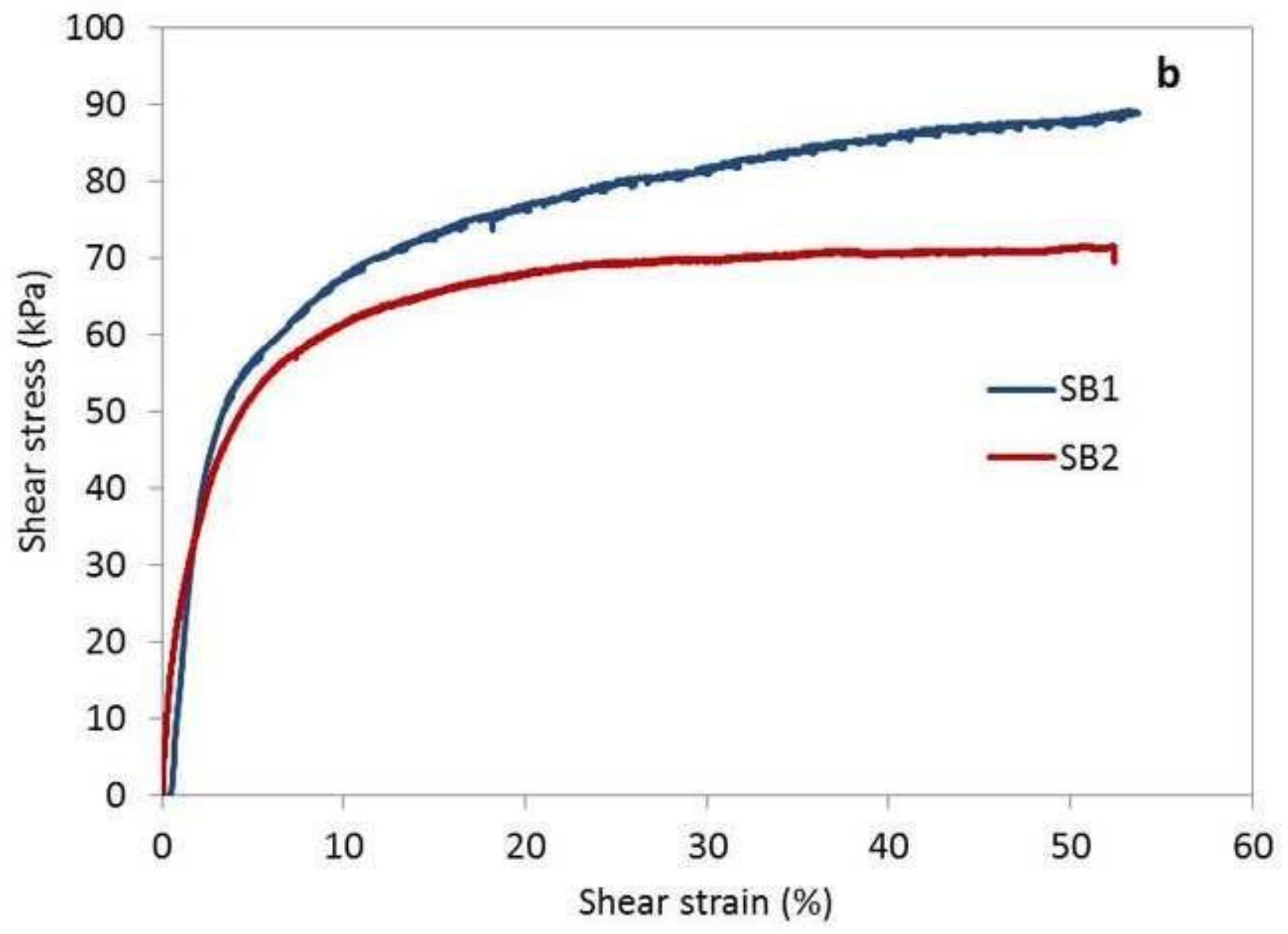




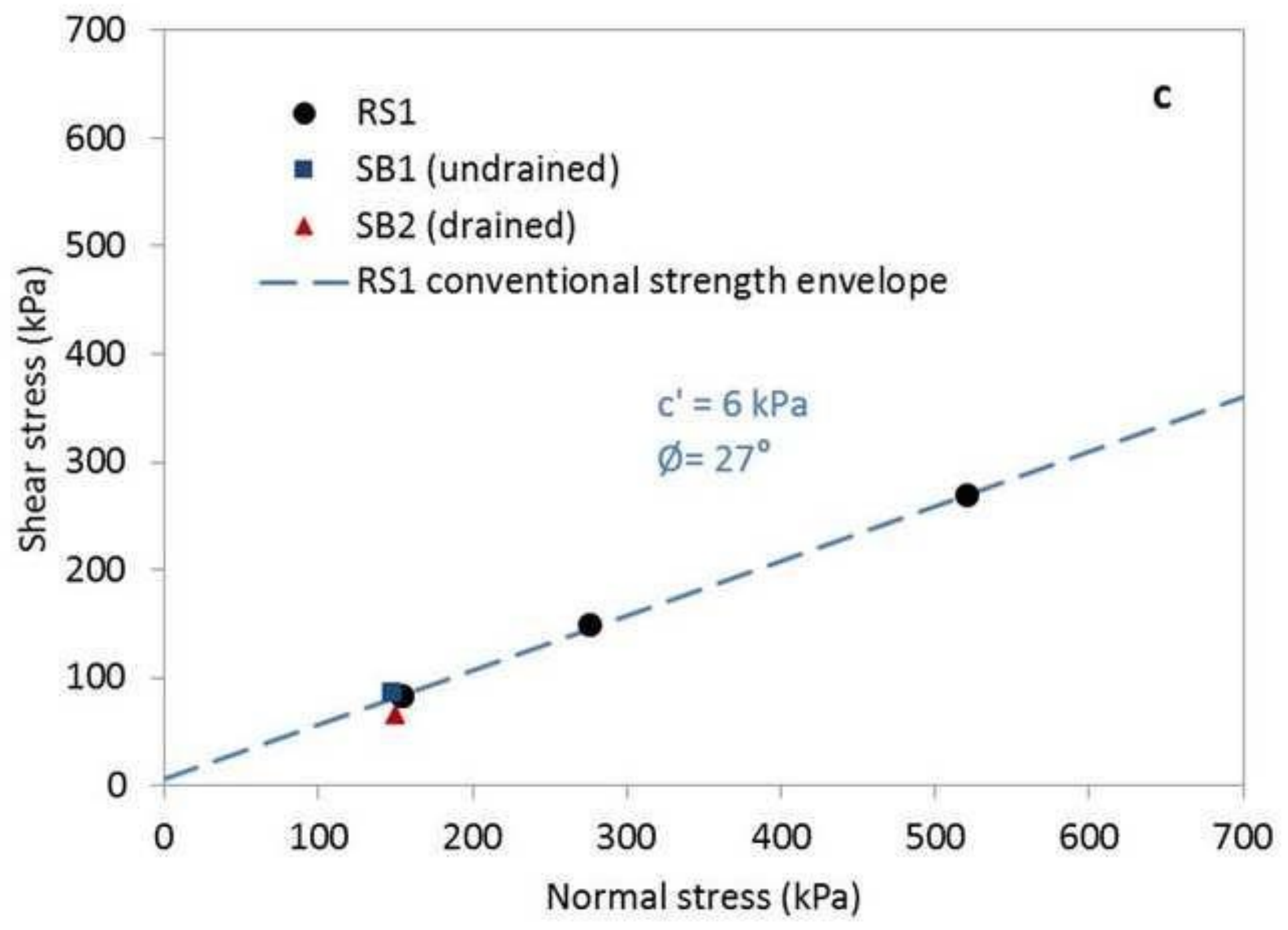




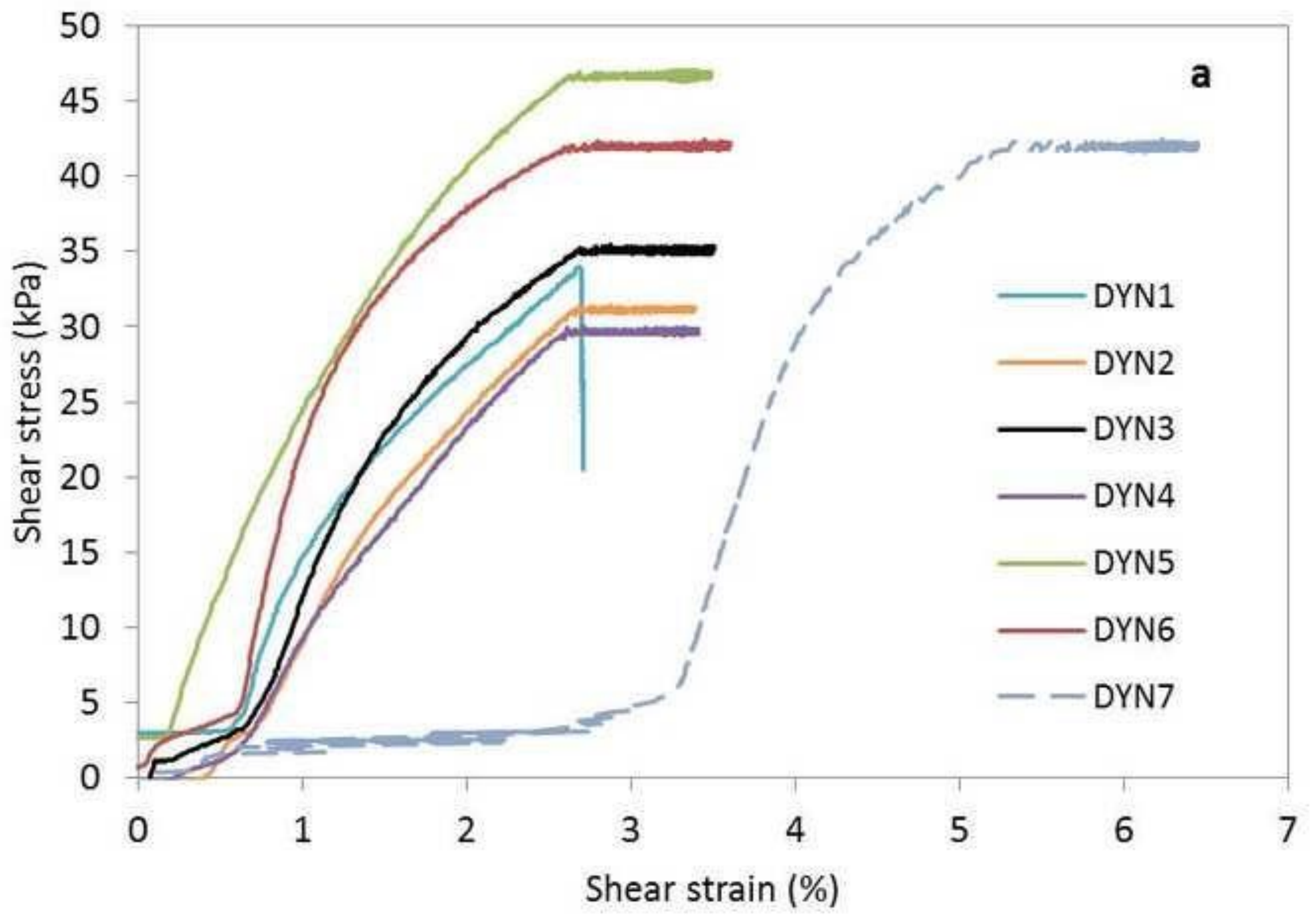




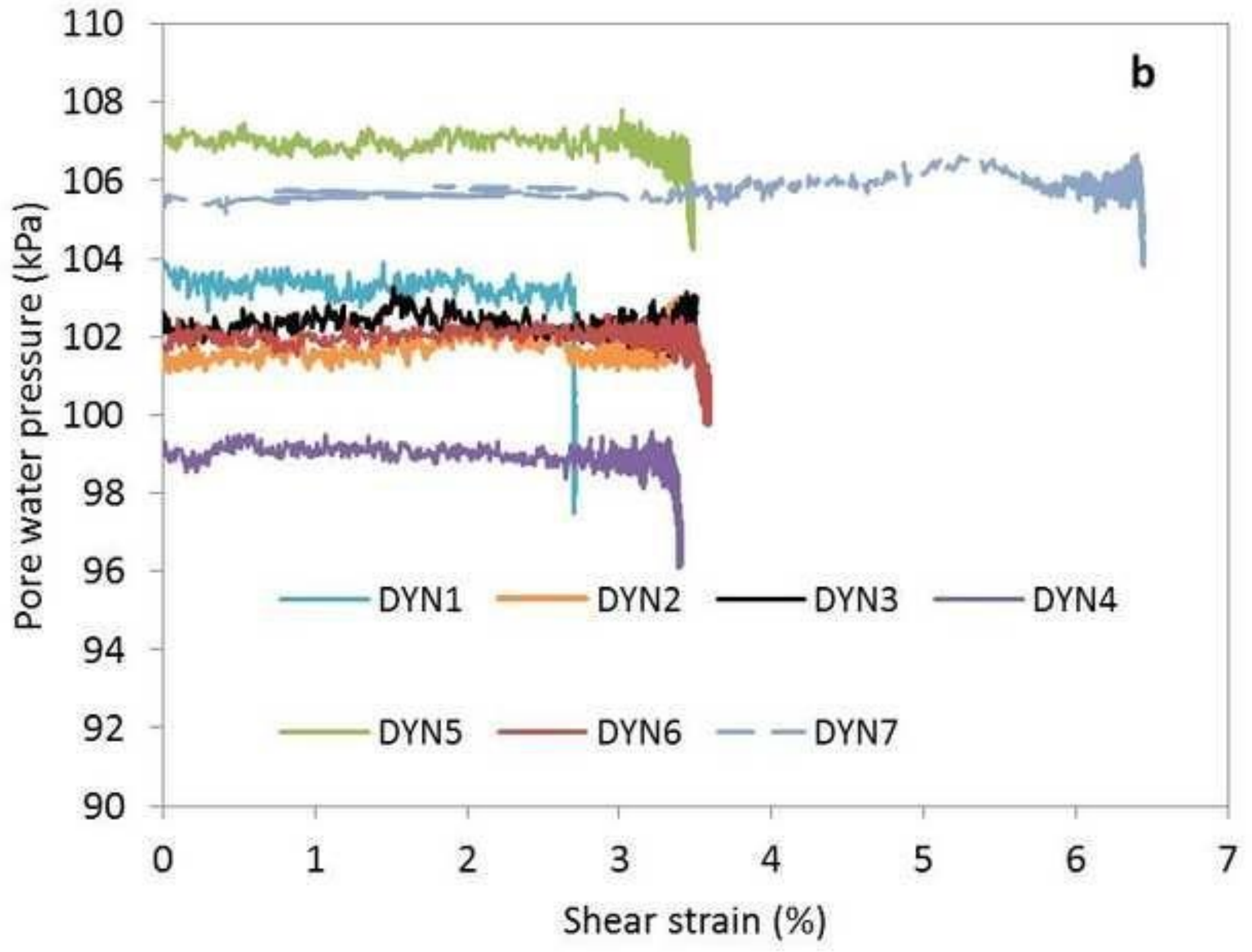




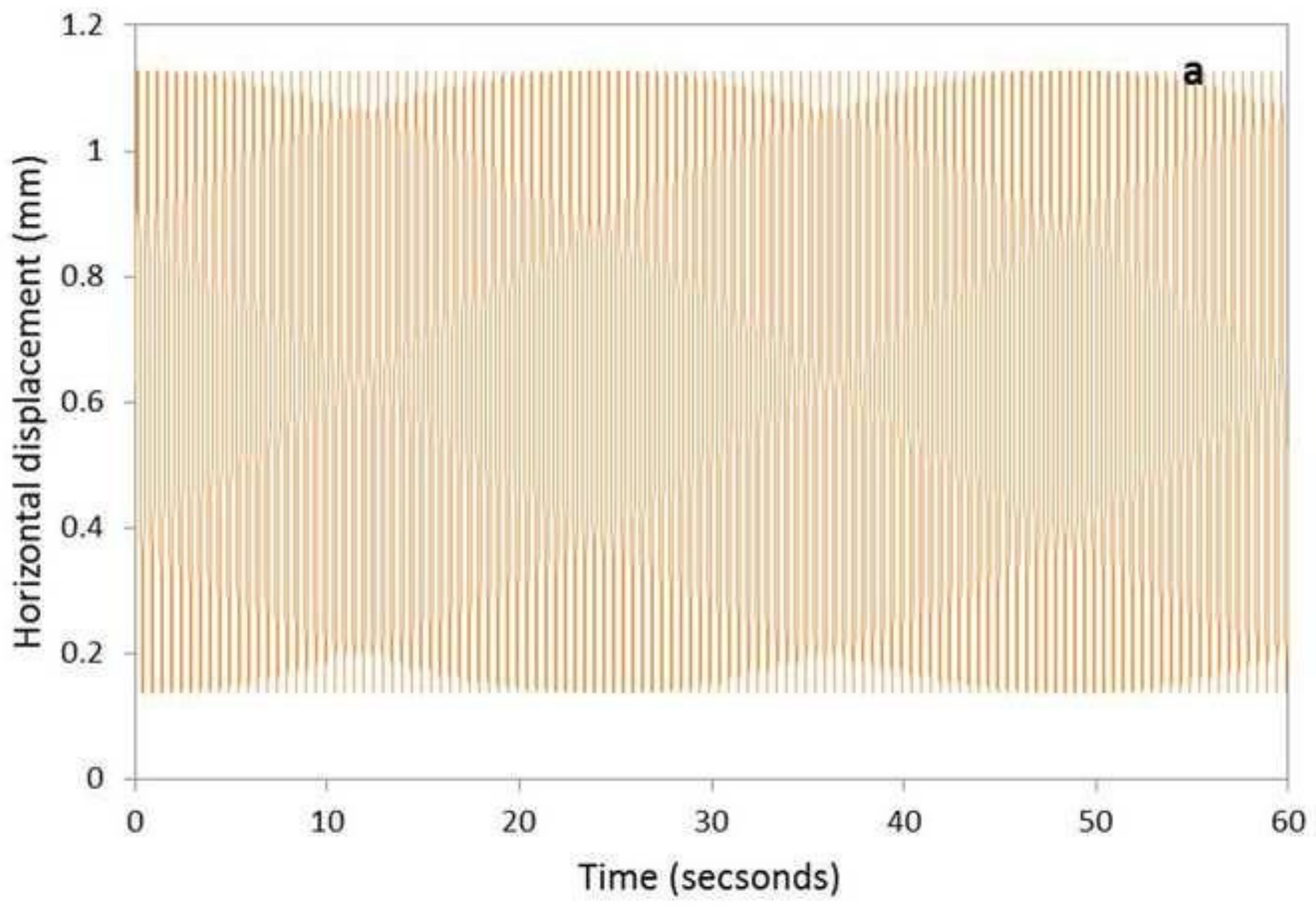




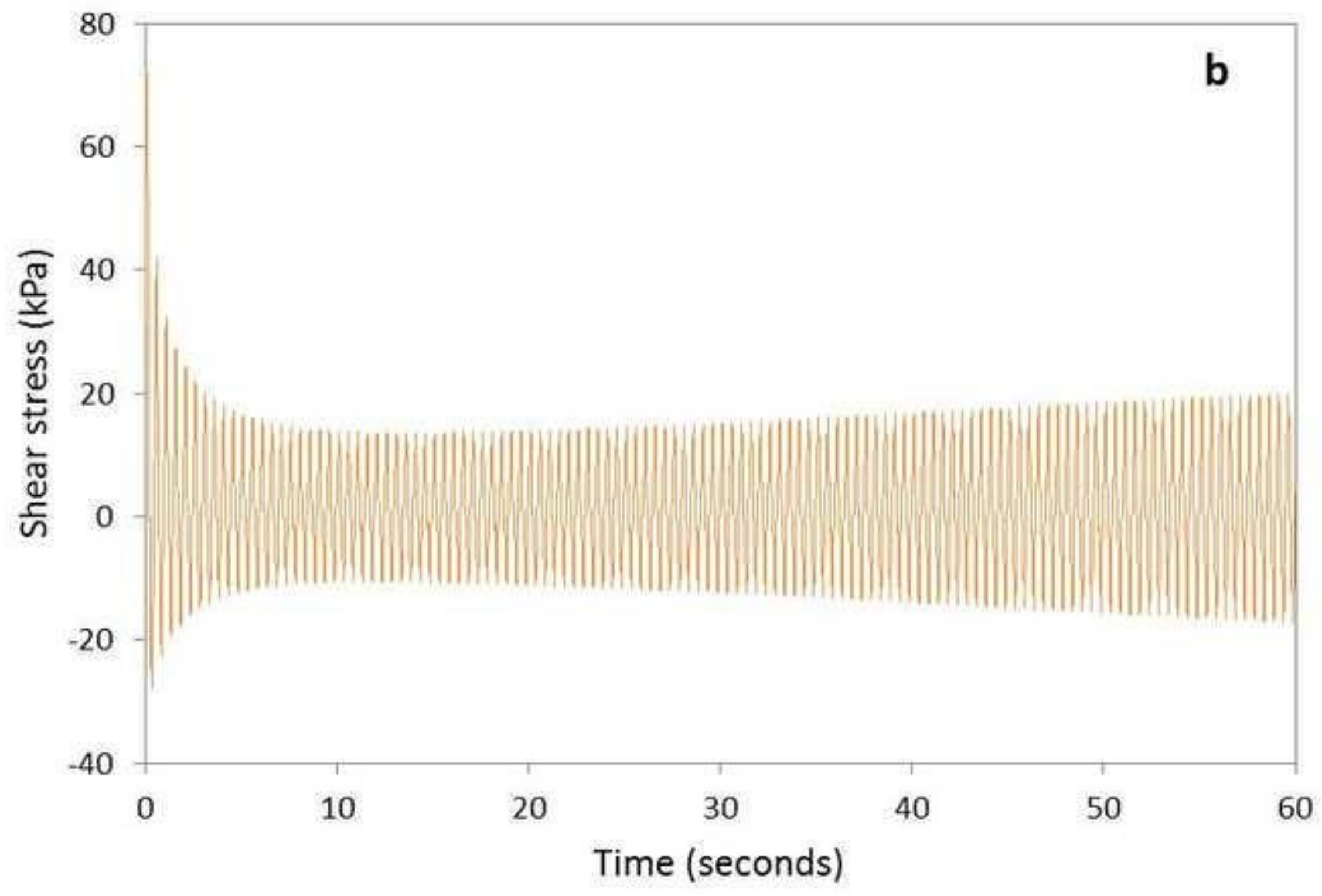




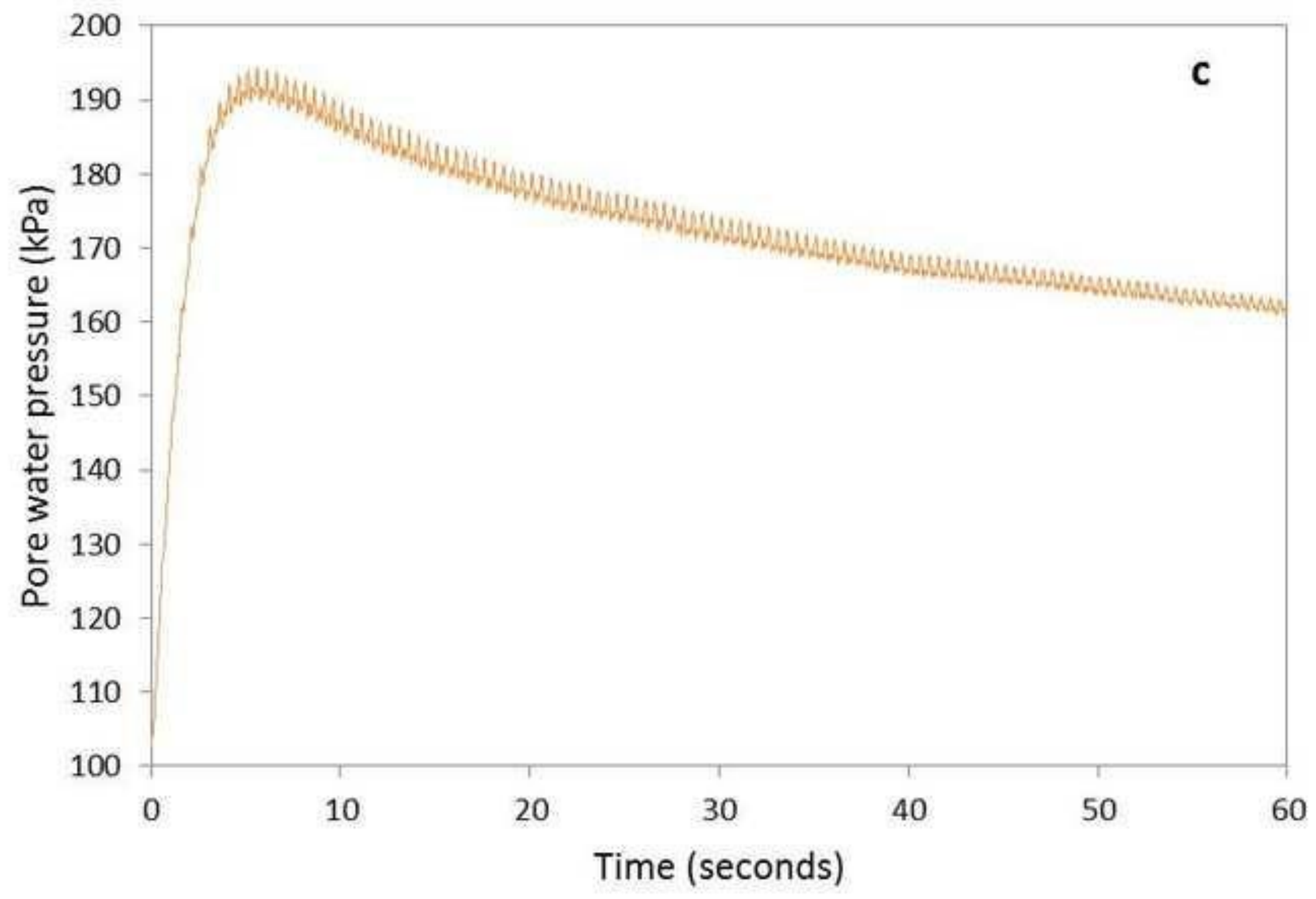




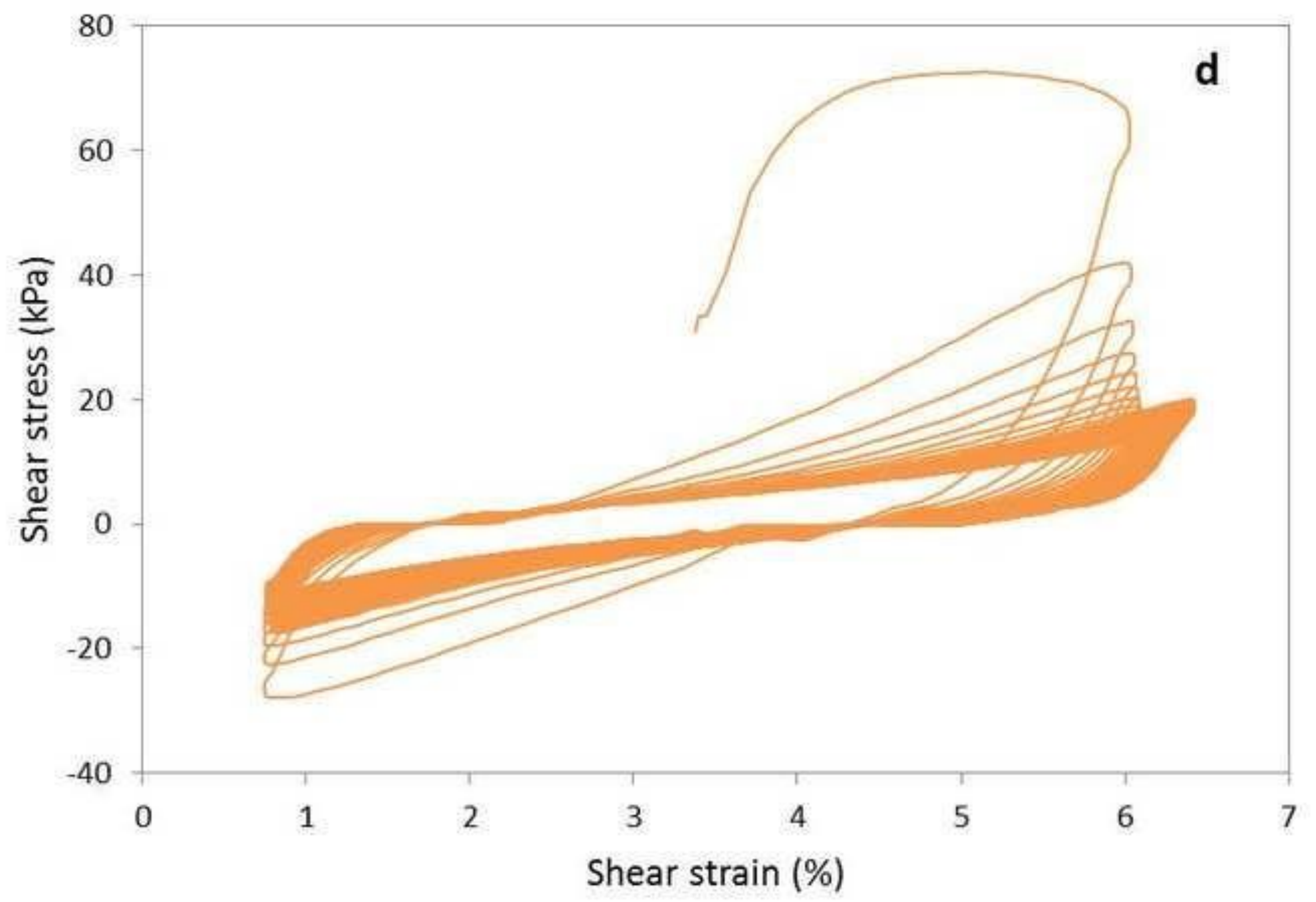




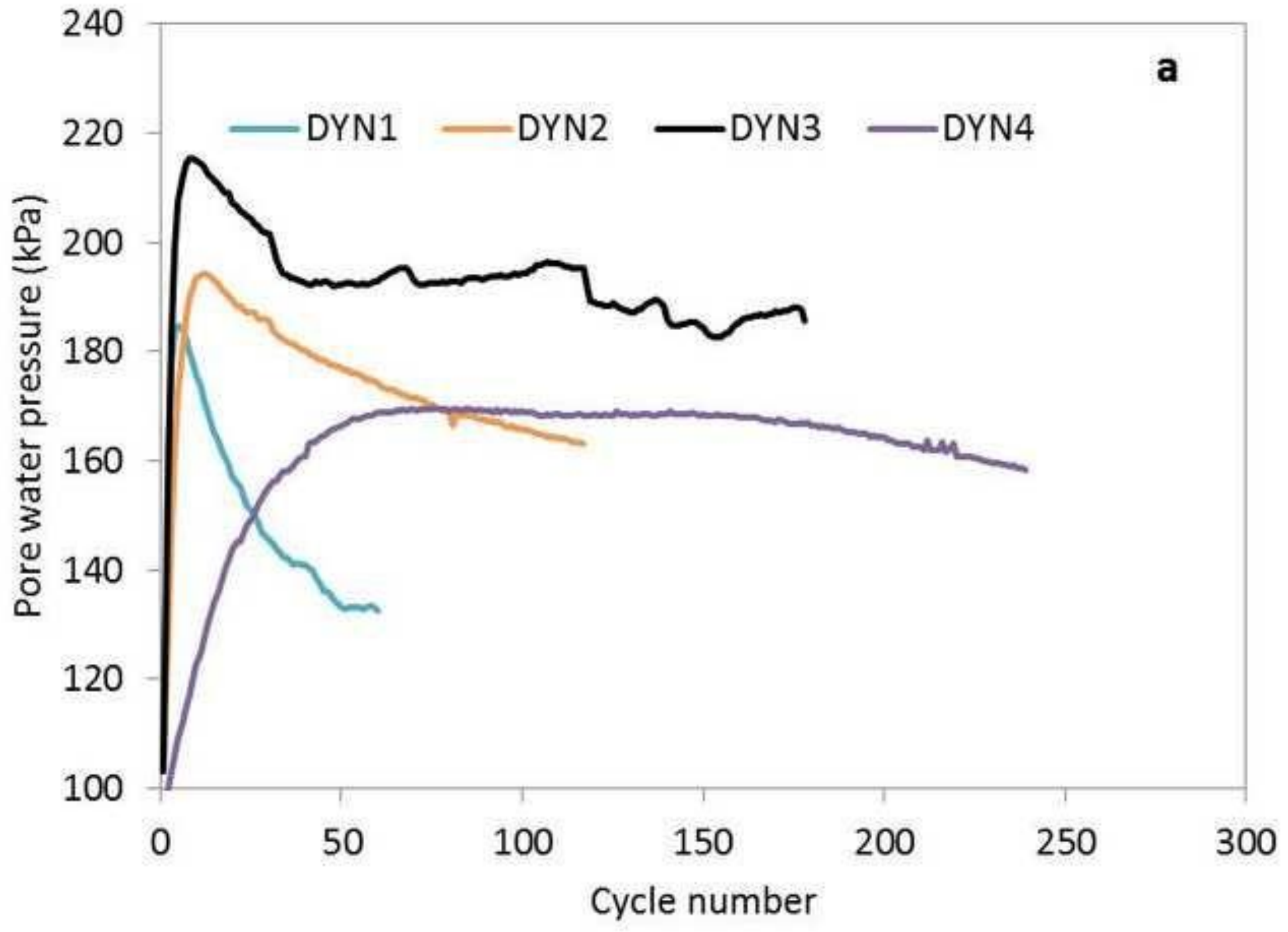




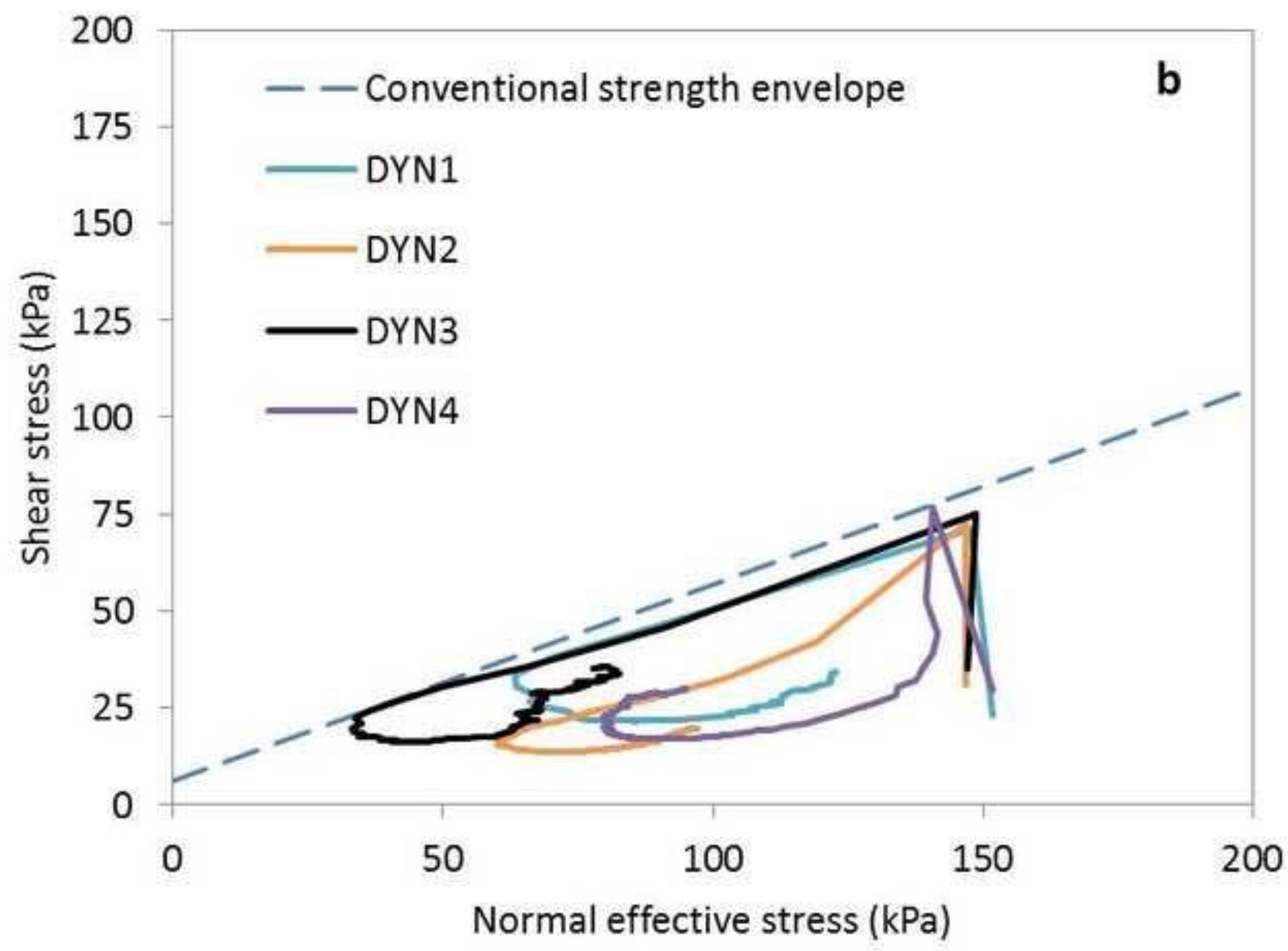




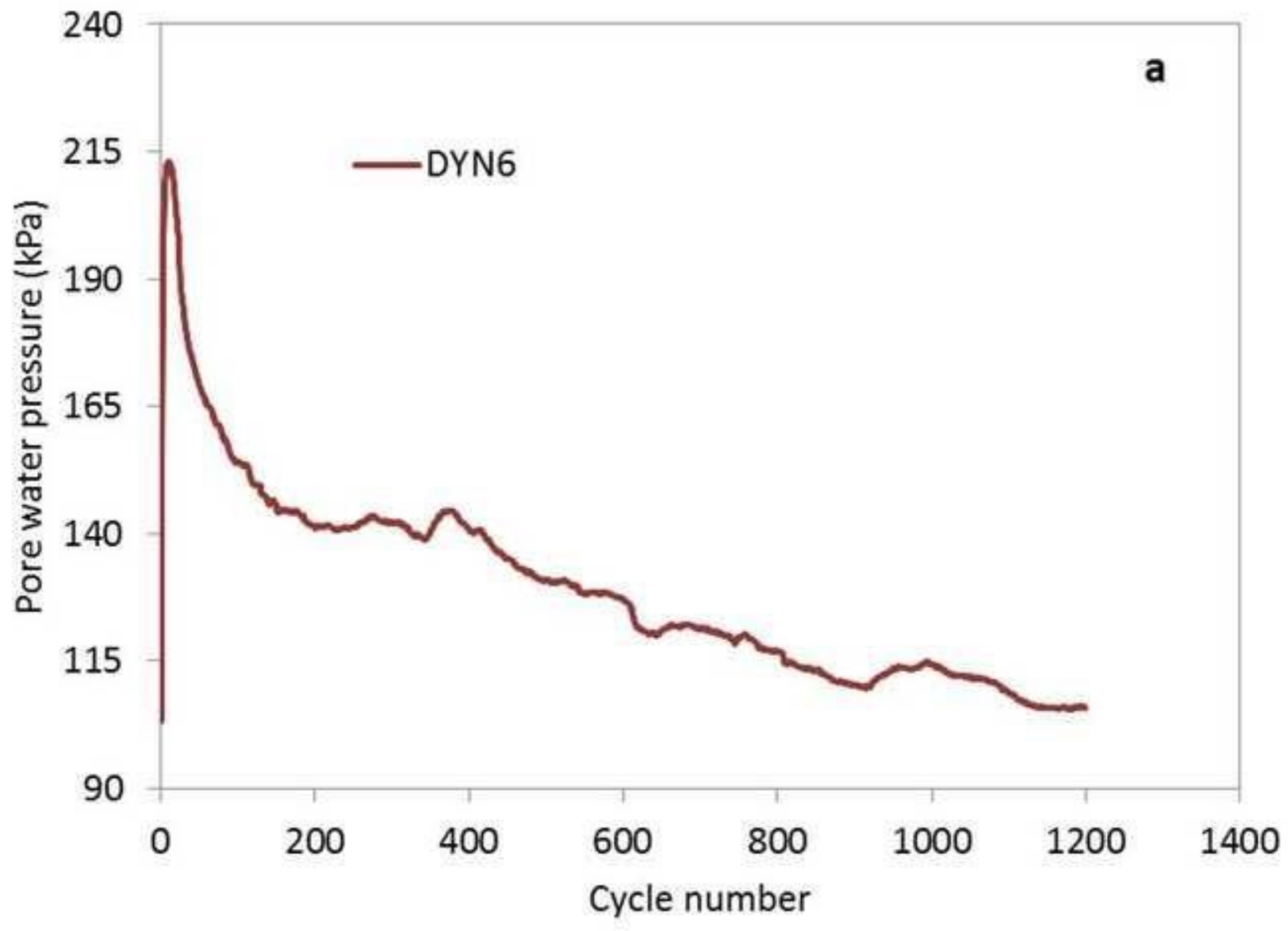




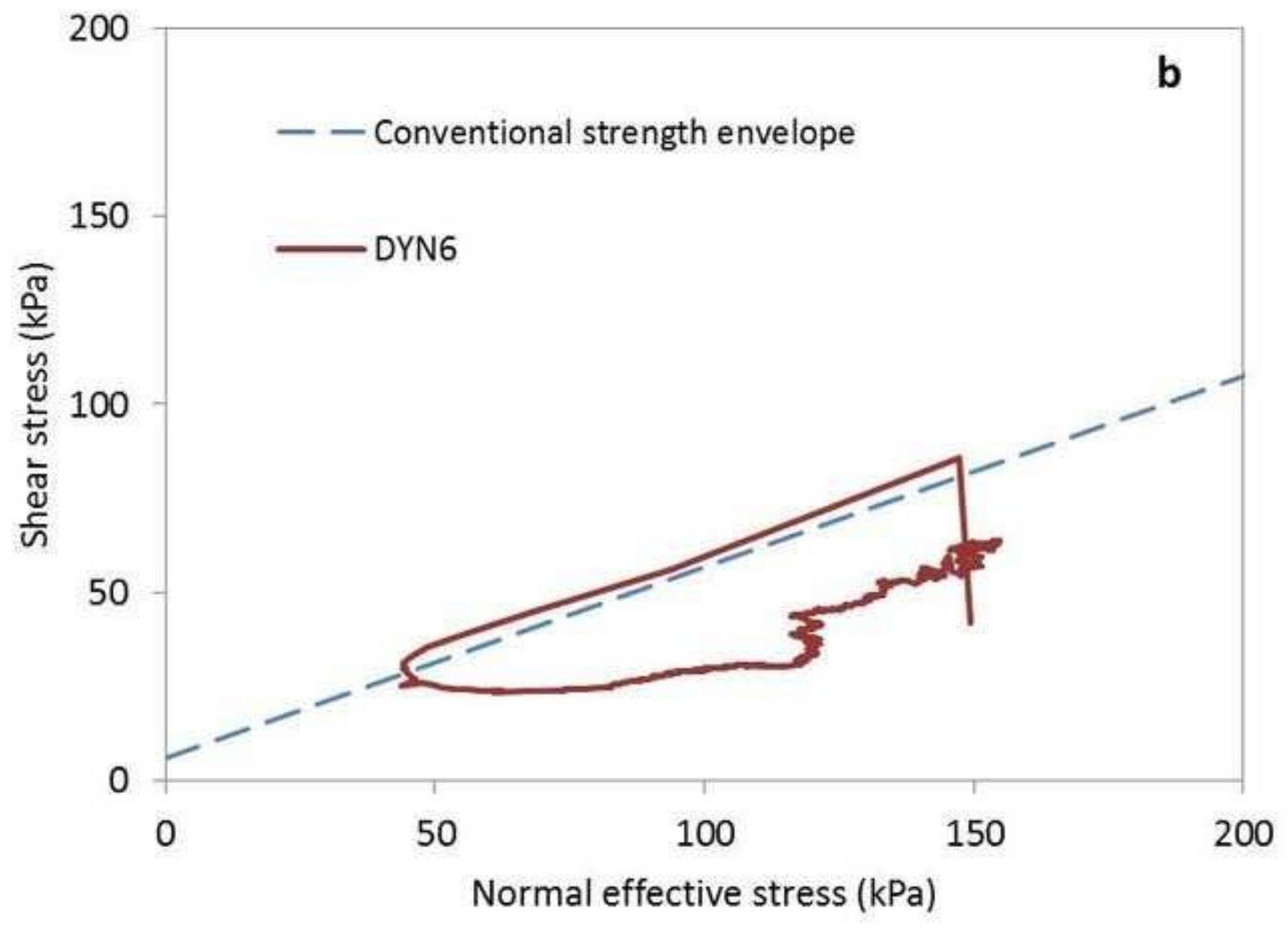




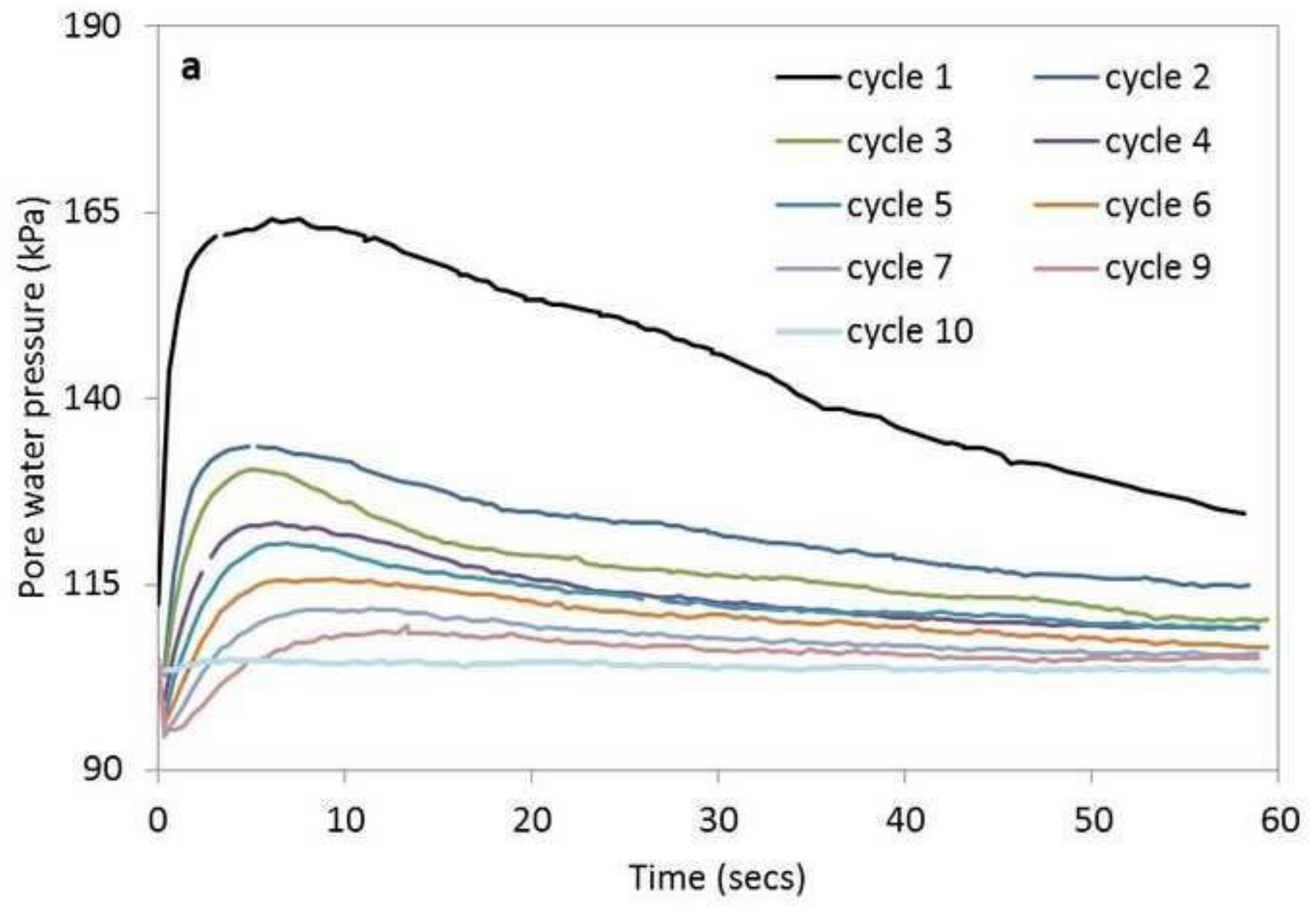




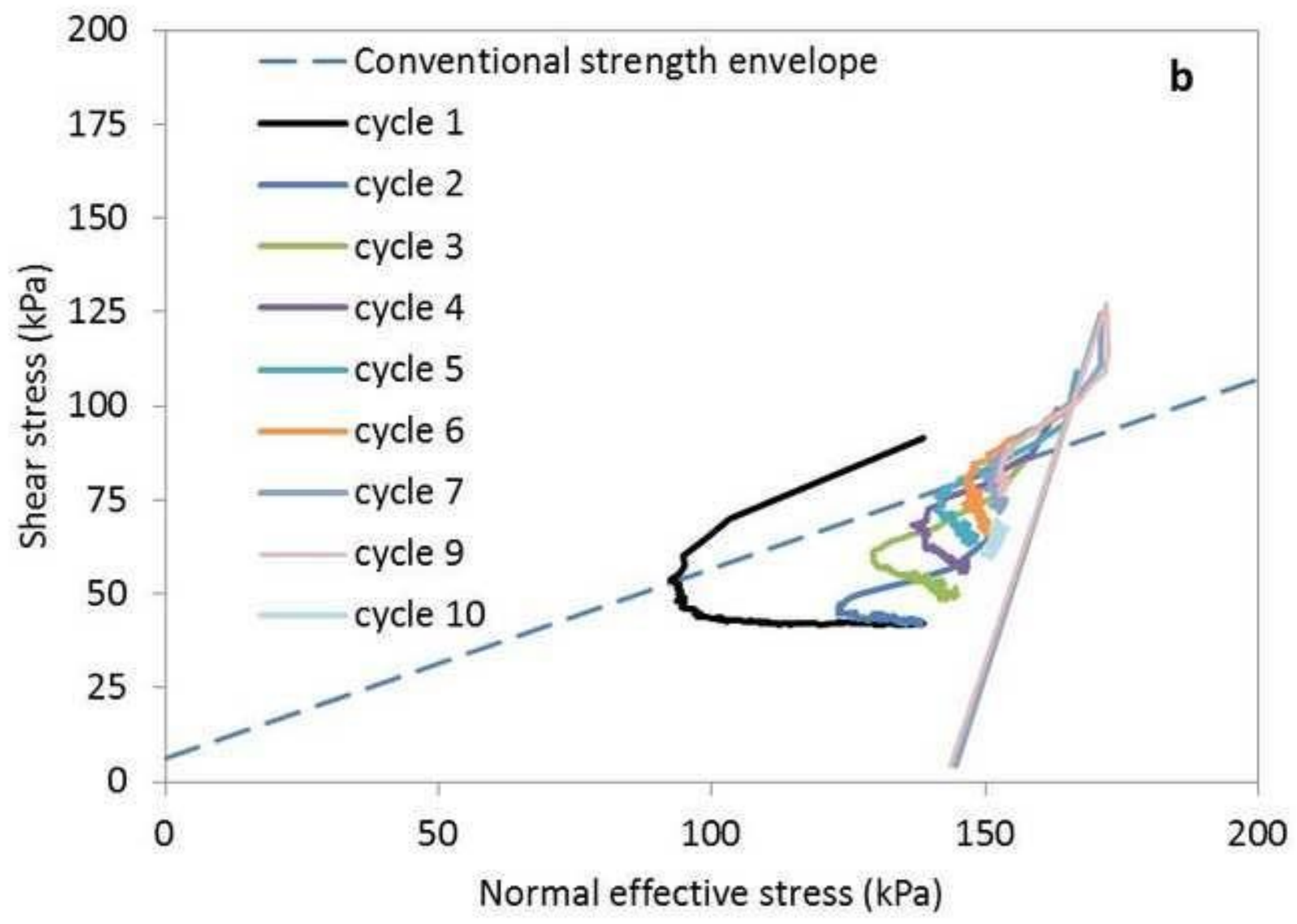




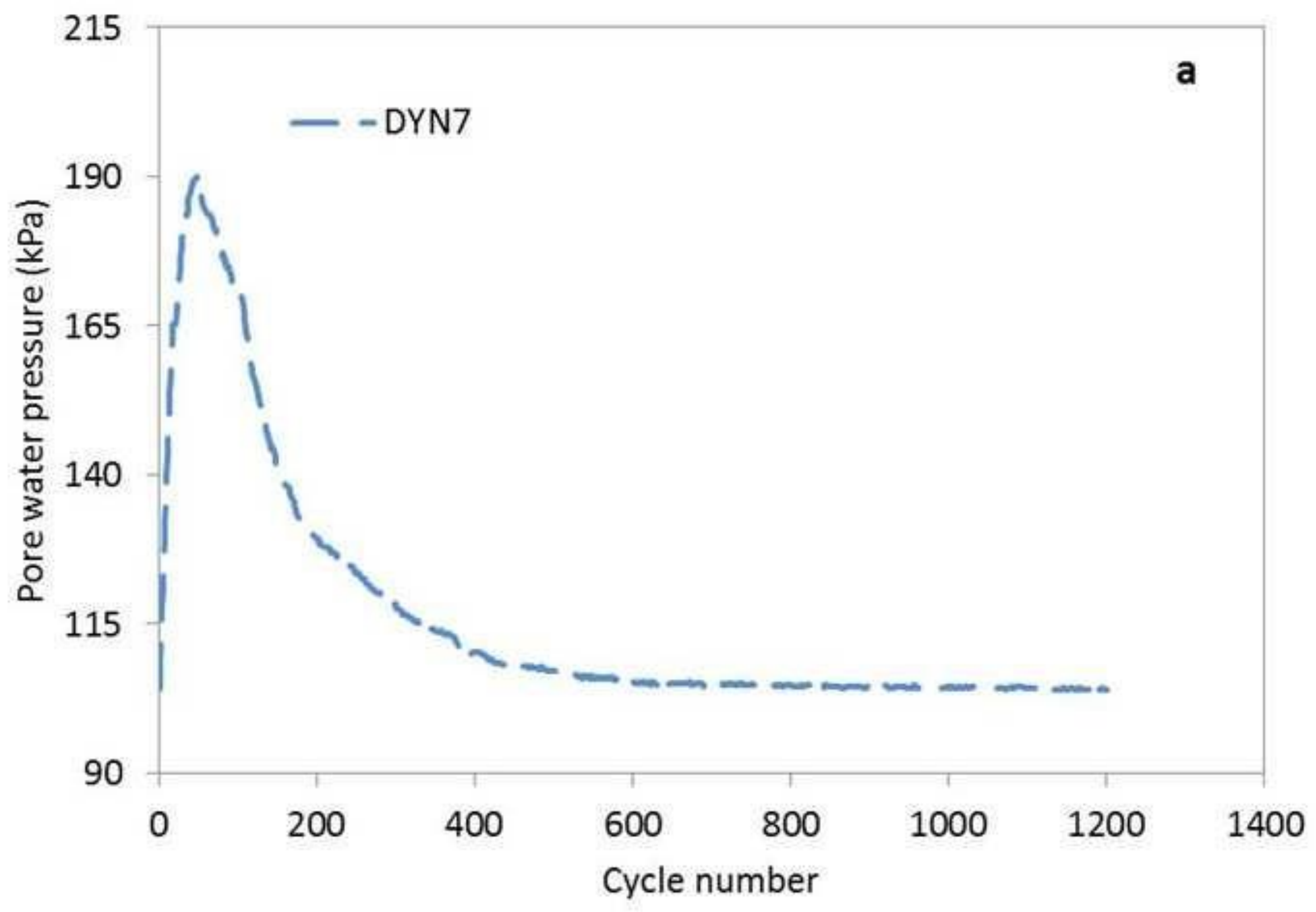




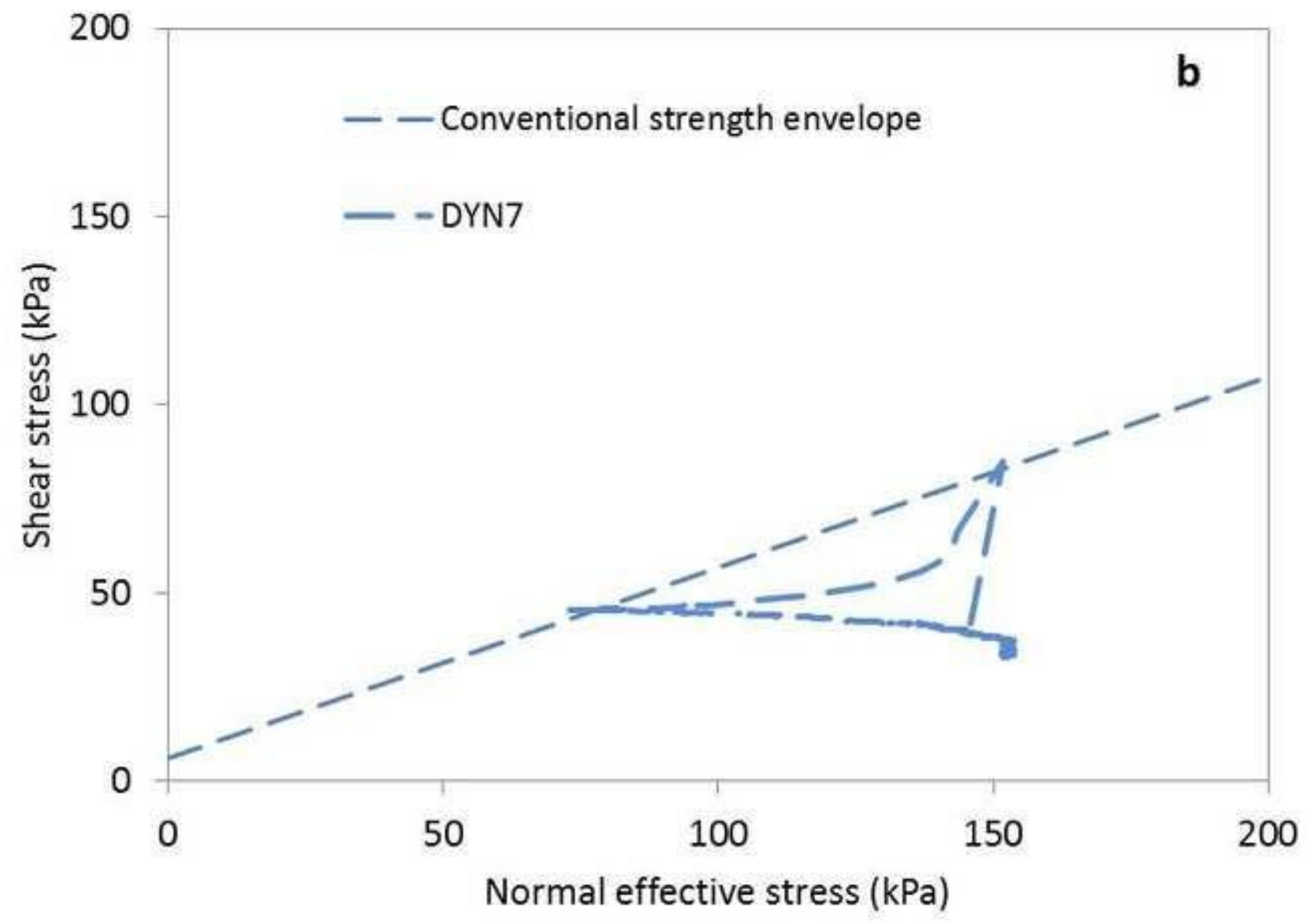




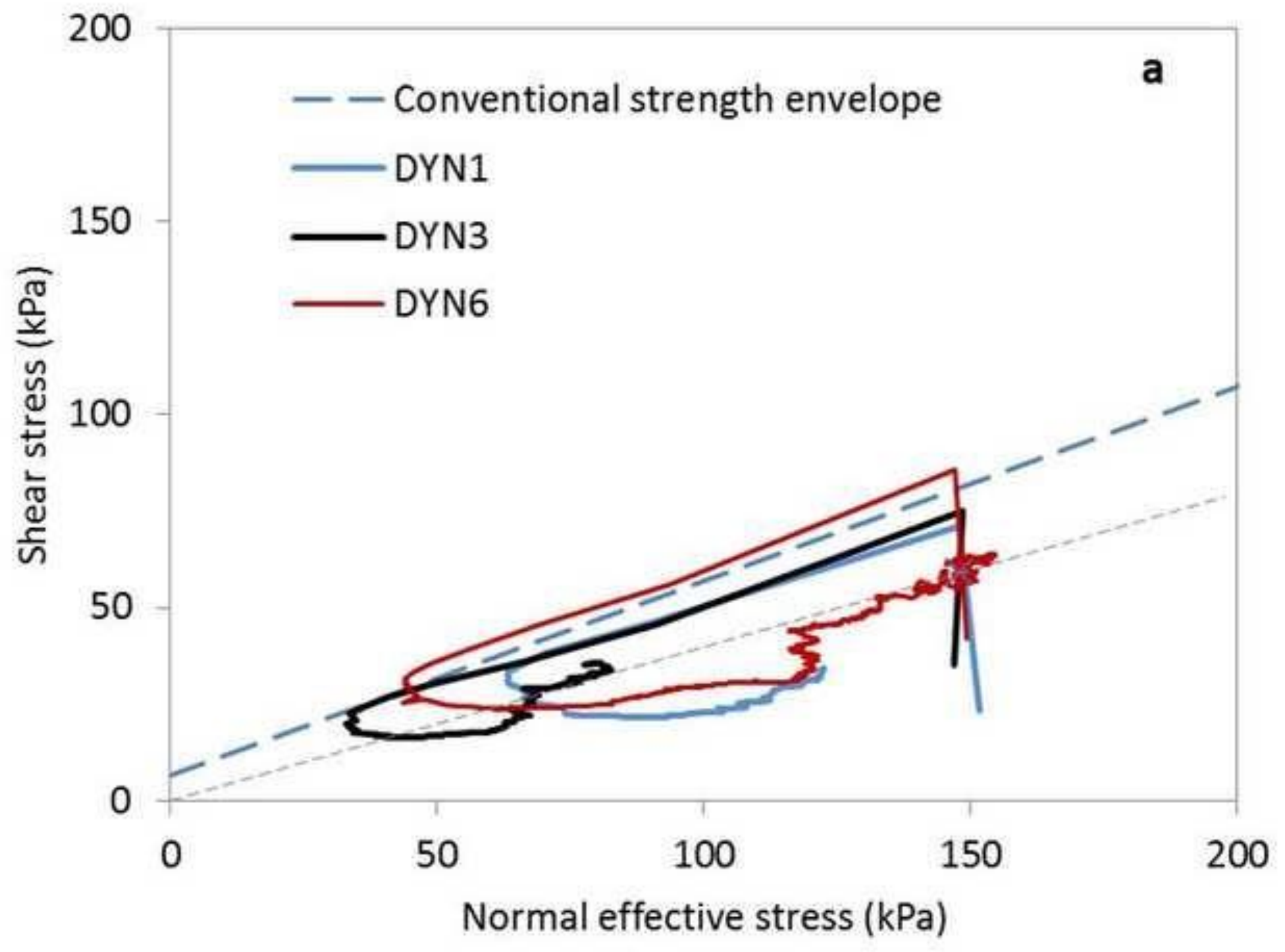




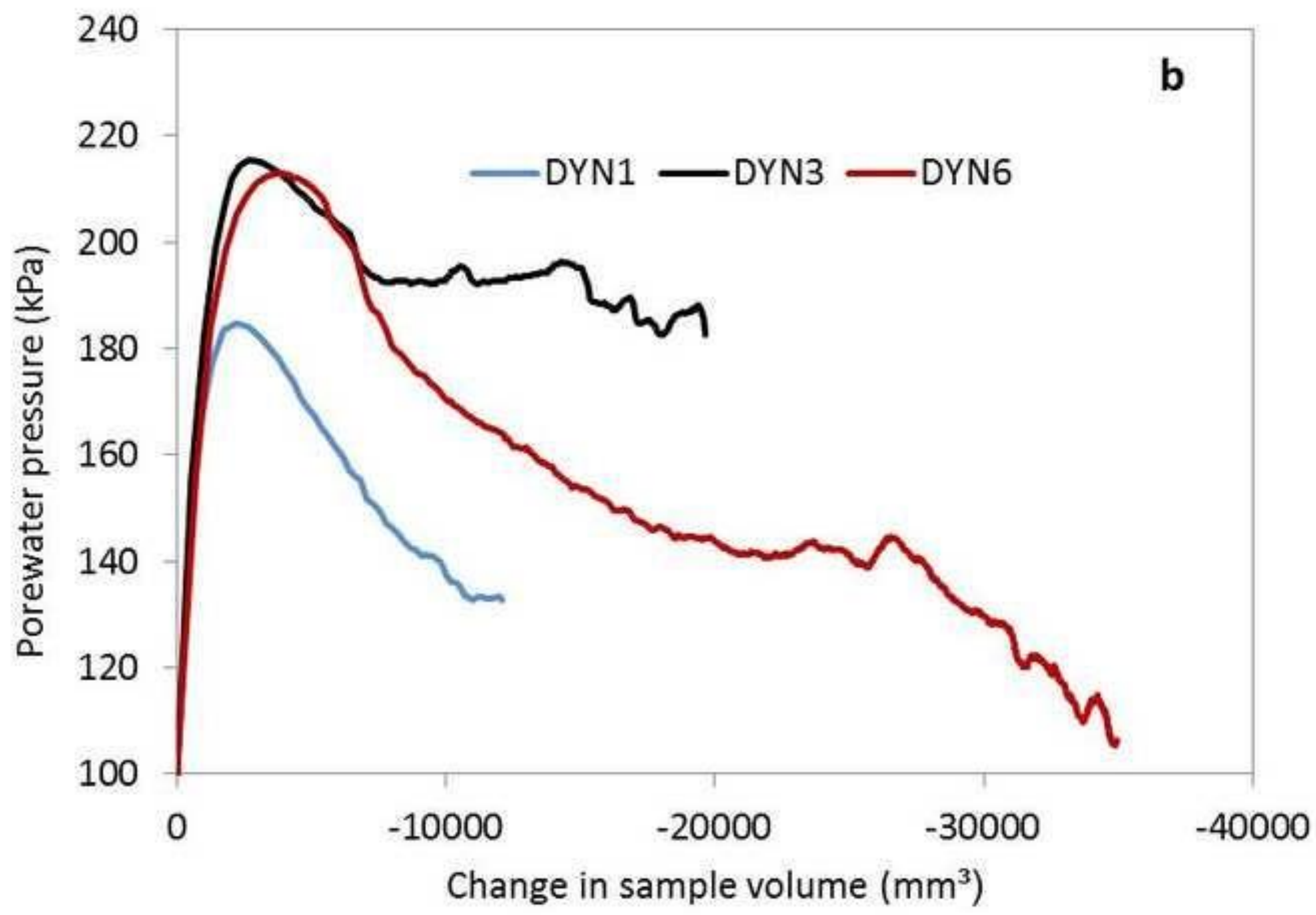




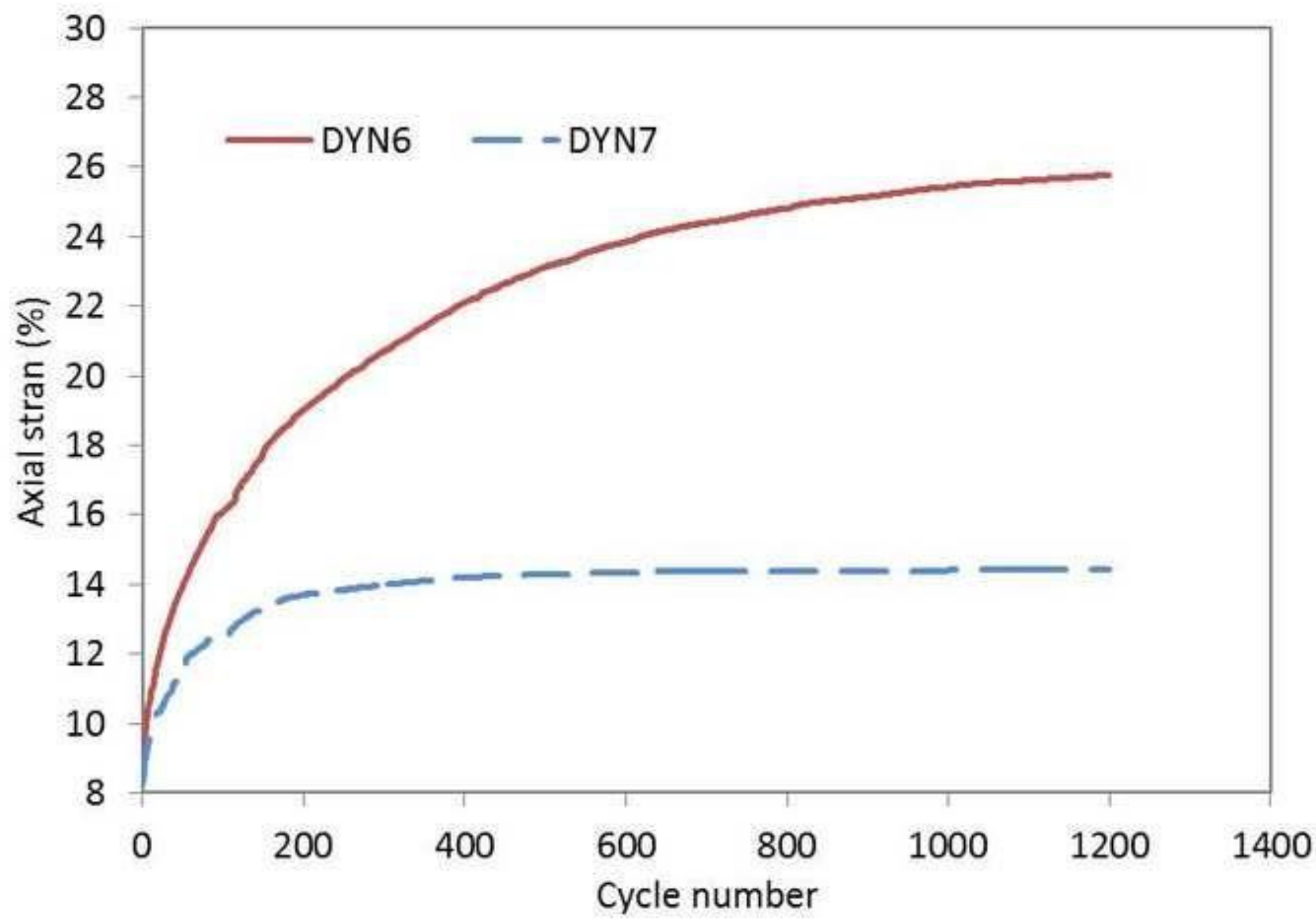




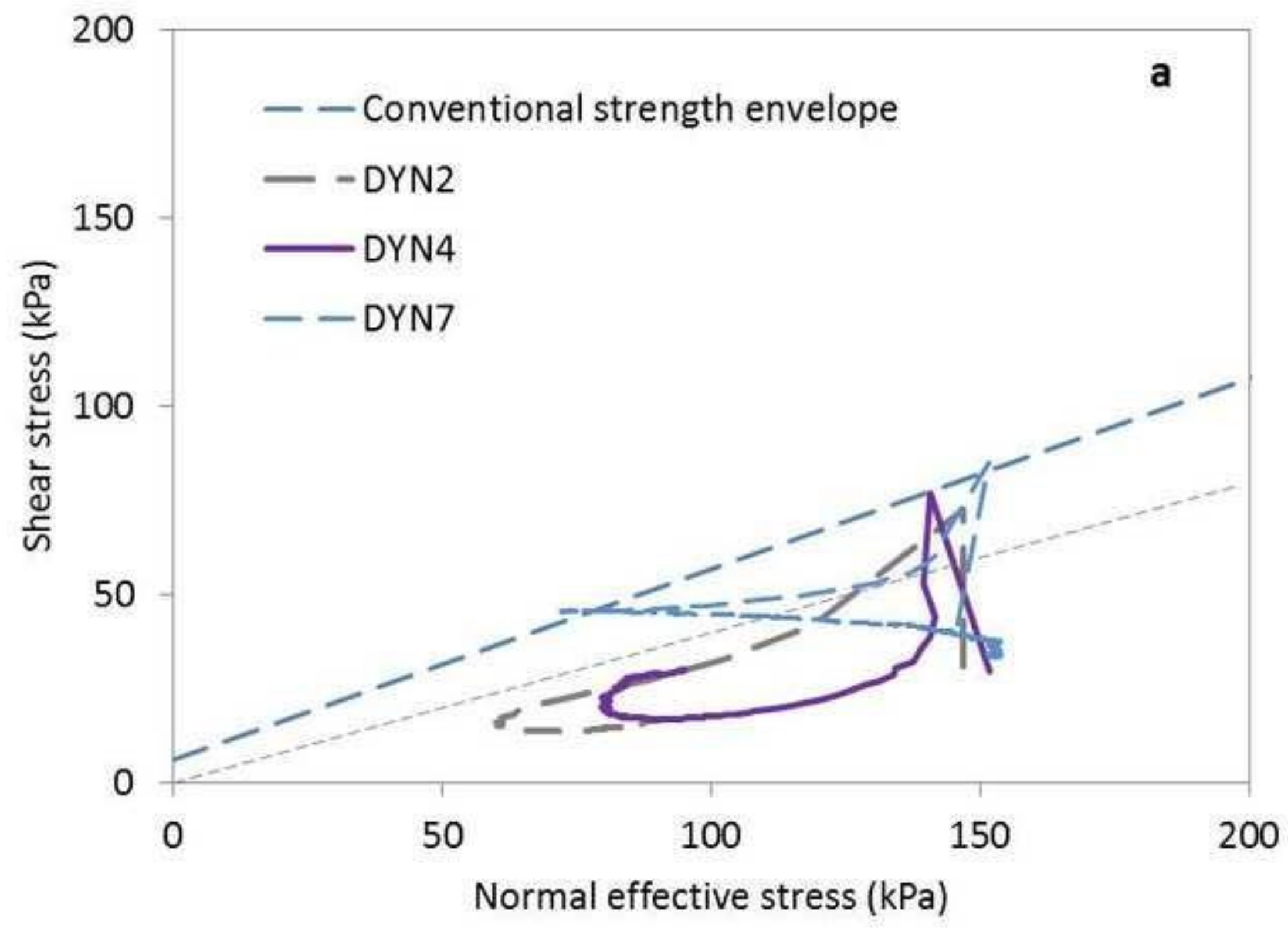




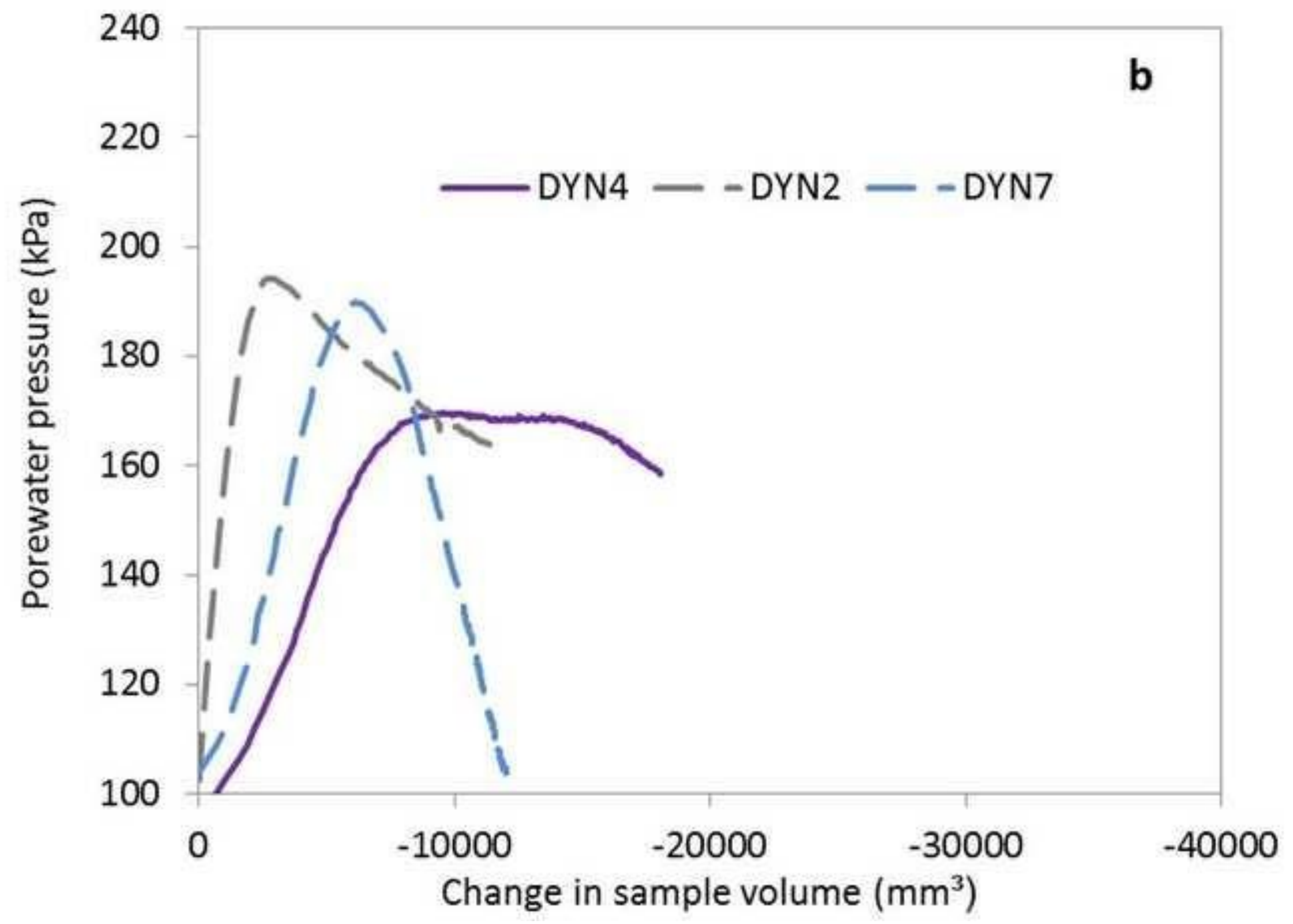




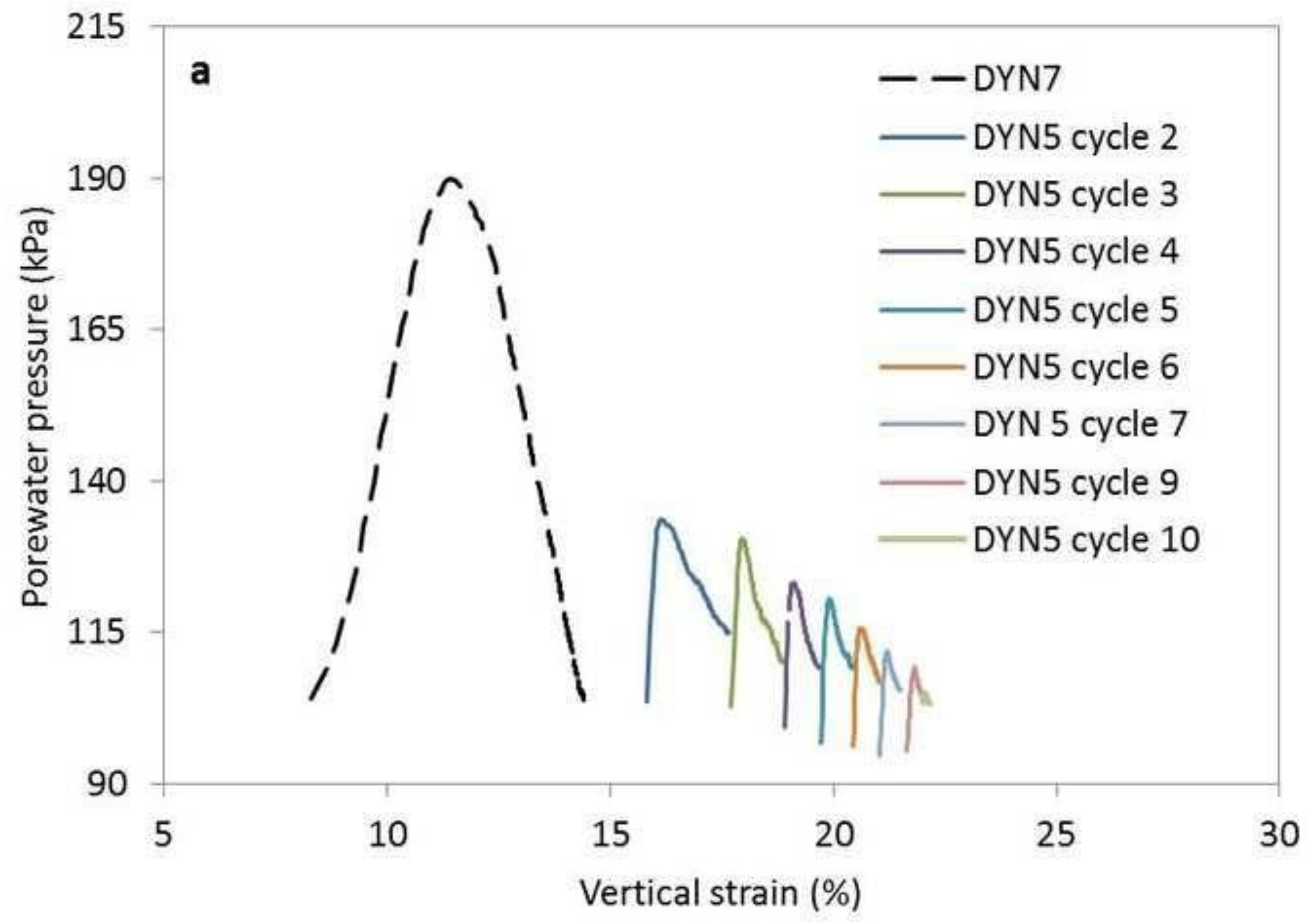




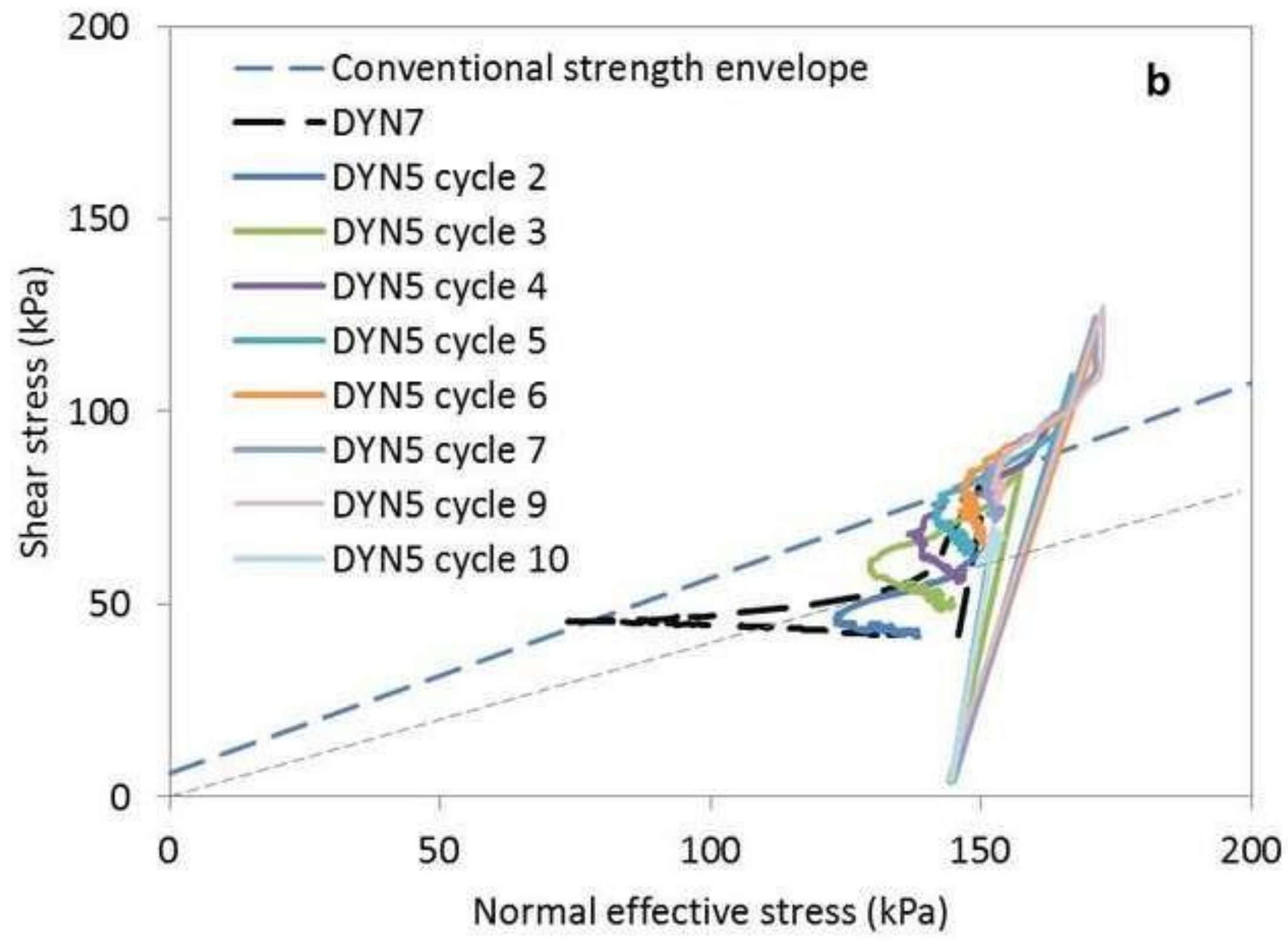




\begin{tabular}{cc}
\hline Physical property & Maffeys Road \\
\hline Mc (\%) & 9.1 \\
Liquid limit (\%) & 25 \\
Plastic limit (\%) & 16 \\
Plasticity index & 9 \\
Bulk density $\left(\mathrm{mg} / \mathrm{m}^{3}\right)$ & $1.66-1.76$ \\
Dry density $\left(\mathrm{Mg} / \mathrm{m}^{3}\right)$ & $1.53-1.61$ \\
Initial void ratio & $0.64-0.71$ \\
\hline
\end{tabular}




\begin{tabular}{|c|c|c|c|c|c|c|c|}
\hline $\begin{array}{c}\text { Sample } \\
\text { Reference }\end{array}$ & Test type & $\begin{array}{l}\text { Initial } \\
\text { confining } \\
\text { pressure } \\
(\mathrm{kPa})\end{array}$ & $\begin{array}{l}\text { Initial shear } \\
\text { rate to } 0.5 \\
\quad \mathrm{~mm} \\
(\mathrm{~mm} / \mathrm{min})\end{array}$ & $\begin{array}{c}\text { Dynamic } \\
\text { confining } \\
\text { pressure } \\
(\mathrm{kPa})\end{array}$ & $\begin{array}{l}\text { Dynamic hor } \\
\text { Displacement } \\
+/-(\mathrm{mm})\end{array}$ & $\begin{array}{c}\text { Frequency } \\
(\mathrm{Hz})\end{array}$ & $\begin{array}{c}\text { Number of } \\
\text { cycles } \\
\text { (cycles } x \text { secs) }\end{array}$ \\
\hline RS1 & ring shear & 154 & 0.0178 & - & - & - & - \\
\hline SB1 & $\begin{array}{l}\text { drained } \\
\text { shear }\end{array}$ & 148 & 0.01 & - & - & - & - \\
\hline SB2 & $\begin{array}{l}\text { undrained } \\
\text { shear }\end{array}$ & 148 & 0.01 & - & - & - & - \\
\hline DYN1 & $\begin{array}{l}\text { dynamic } \\
\text { shear }\end{array}$ & 150 & 0.01 & 150 & 0.5 & 1 & $60(1 \times 60)$ \\
\hline DYN2 & $\begin{array}{l}\text { dynamic } \\
\text { shear }\end{array}$ & 150 & 0.01 & 150 & 0.5 & 2 & $120(1 \times 120)$ \\
\hline DYN3 & $\begin{array}{l}\text { dynamic } \\
\text { shear }\end{array}$ & 150 & 0.01 & 150 & 0.5 & 3 & $180(1 \times 180)$ \\
\hline DYN4 & $\begin{array}{l}\text { dynamic } \\
\text { shear }\end{array}$ & 150 & 0.01 & 150 & 0.5 & 4 & $240(1 \times 240)$ \\
\hline DYN5 & $\begin{array}{l}\text { dynamic } \\
\text { shear }\end{array}$ & 150 & 0.01 & 150 & 0.5 & 2 & $600(10 \times 60)$ \\
\hline DYN6 & $\begin{array}{l}\text { dynamic } \\
\text { shear }\end{array}$ & 150 & 0.01 & 150 & 0.5 & 2 & $600(1 \times 600)$ \\
\hline DYN7* & $\begin{array}{l}\text { dynamic } \\
\text { shear }\end{array}$ & 150 & 0.01 & 150 & 0.5 & 2 & $600(1 \times 600)$ \\
\hline
\end{tabular}

